\title{
Panorama das publicações científicas sobre o rompimento da Barragem de Fundão (Mariana-MG): subsídios às investigações sobre o maior desastre ambiental do país
}

\section{Panorama of the scientific publications about the rupture of the Fundão Dam (Mariana-MG): subsidies for investigations into the country's biggest environmental disaster}

Daniel Machado Facury Graduando em Geografia pela Universidade Federal de Minas Gerais, Brasil danielfacury@gmail.com

Victor José Brey-Gil Brito de Carvalho Graduando em Geografia pela Universidade Federal de Minas Gerais, Brasil breycarvalho@hotmail.com

Guilherme Eduardo Macedo Cota Mestrando em Geografia e Análise Ambiental pela Universidade Federal de Minas Gerais, Brasil guilhermebhmg@hotmail.com

Antônio Pereira Magalhães Junior Professor Doutor do Departamento de Geografia da Universidade Federal de Minas Gerais, Brasil antonio.magalhaes.ufmg@gmail.com

Luiz Fernando de Paula Barros Professor Doutor do Departamento de Geografia da Universidade Federal de Minas Gerais, Brasil luizfpbarros@yahoo.com

\begin{abstract}
Resumo
O rompimento da barragem de rejeitos de minério de Fundão (Mariana-MG) no ano de 2015 é considerado o mais grave desastre ambiental já ocorrido em território nacional e suscitou diversas pesquisas acerca dos seus efeitos para a bacia do Rio Doce. Nesse sentido, o presente trabalho propõe sistematizar os estudos realizados sobre as consequências do rompimento a partir de um levantamento bibliográfico de fontes diversas (livros, periódicos, anais de eventos, trabalhos de conclusão de curso, dissertações e teses), considerando o recorte temporal de 05/11/2015 a 15/02/2019. Os resultados obtidos indicam uma maior contribuição de publicações das instituições de pesquisa espacialmente próximas à área afetada pelo desastre, a saber: UFMG, UFJF, UFOP e UFES. Os autores em evidência nas publicações são vinculados à biologia, geografia, comunicação/jornalismo e direito. Vale destacar a baixa presença de publicações associadas a pesquisadores vinculados à geologia, engenharia geológica e engenharia de minas, campos da ciência diretamente associados às atividades de prospecção e exploração mineral.
\end{abstract}

Palavras-chave: Riscos ambientais; Barragens de rejeitos; Mineração de ferro; Quadrilátero Ferrífero. 


\begin{abstract}
The Fundão Dam tailings spill (Mariana, Minas Gerais state) in 2015 is considered the worst environmental disaster that has ever occurred in Brazil and has raised many types of research about its effects in the Doce River Basin. This work aims to systematise the studies about the consequences of the dam disruption by doing a bibliographic survey from diverse sources (books, periodicals, congress annals, monographs, dissertations and thesis) considering the period of $11 / 05 / 2018$ to $02 / 15 / 2019$. Most of the publications are from the research institutions spatially close to the disaster-affected area. The authors are linked to biology, geography, communication, journalism and environmental law. There is a reduced contribution of researches from geology, geological engineering and mining engineering, even though these science fields are directly associated to the prospection and mineral exploration activities.
\end{abstract}

Keywords: Environmental risks; Tailings Dam; Iron Mining; Iron province of Minas Gerais.

\title{
1. INTRODUÇÃO
}

A barragem de Fundão pertence à mineradora Samarco S.A. e está localizada no município de Mariana, em Minas Gerais. O rompimento da barragem ocorreu no dia 05 de novembro de 2015, levando ao lançamento de cerca de 60 bilhões de litros de rejeito de minério liquefeito aos sistemas fluviais subjacentes à barragem (MILANEZ; LOSEKANN, 2016). Dada a sua magnitude, este evento pode ser definido como um dos mais graves desastres envolvendo barragens de rejeito de mineração no Brasil, principalmente em decorrência dos danos e prejuízos ambientais gerados para os meios físico, biótico e socioeconômico, alterando drasticamente a paisagem da bacia do rio Doce e de outras artérias fluviais atingidas.

O fluxo de lama oriundo da barragem percorreu o Córrego Fundão, o Córrego Santarém e o Rio Gualaxo do Norte até atingir o Rio do Carmo e, posteriormente, o Rio Doce (figura 1), alterando a morfologia das artérias fluviais atingidas e de seus afluentes que, por sua vez, sofreram refluxo dos rejeitos de minério (VERVLOET, 2016). Parte deste material ficou depositada principalmente nas calhas e planícies dos cursos d'água atingidos (IBAMA, 2015), gerando uma perturbação no equilíbrio hidrossedimentológico da área afetada.

A bacia do rio Doce já apresentava um quadro de significativa fragilidade ambiental anteriormente ao desastre, decorrente das atividades humanas. Historicamente, houve uma intensa redução da vegetação natural em prol do avanço da pecuária (NETO et al., 2016). Em seu estudo sobre a síntese das pressões sobre os recursos hídricos na bacia do rio Doce, Felippe et al. (2016) destacam a inconformidade dos padrões de qualidade das águas para múltiplos rios em variadas porções da bacia. Assim, o rompimento da barragem agravou um quadro de fragilidade ambiental que já se apresentava crítico.

Consoante, desde o desastre, diversos institutos de pesquisa, órgãos públicos e organizações independentes vêm realizando estudos para avaliar a magnitude dos danos ambientais e levantar os prejuízos do rompimento para o meio físico, biótico e socioeconômico. Criada a partir da assinatura 
do Termo de Transação e Ajustamento de Conduta (TTAC) entre a Samarco S. A., suas acionistas Vale e BHP Billiton e órgãos governamentais, a Fundação Renova também realiza estudos na área atingida, além de ações de recuperação dos danos ambientais gerados.

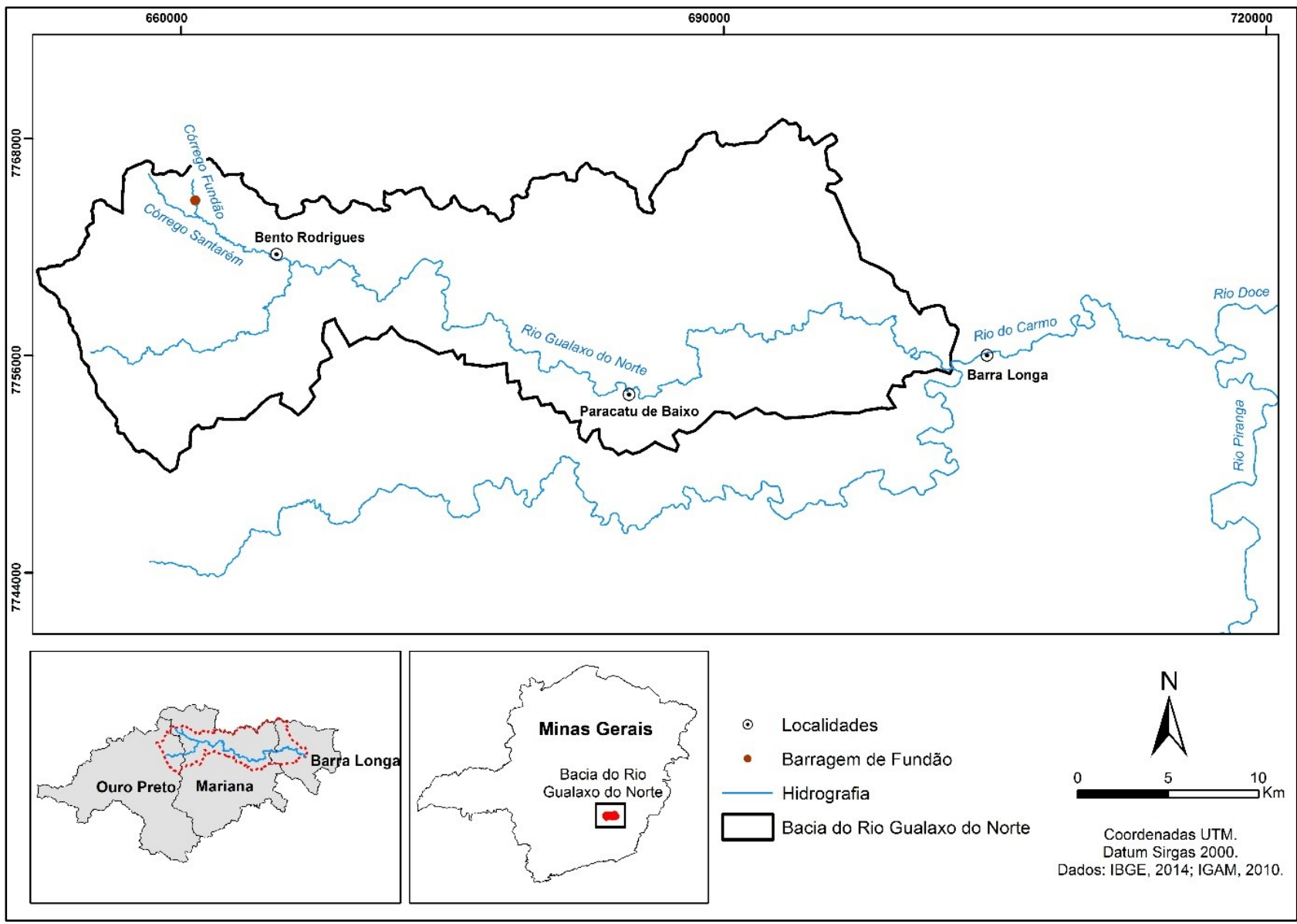

Figura 1 - Localização da barragem de Fundão.

Não obstante, tais estudos permanecem, por vezes, fragmentados e setorizados, evidenciando a ausência de uma sistematização das informações existentes acerca das problemáticas geradas pelo rompimento da barragem. Desse modo, o presente artigo tem como objetivo levantar o panorama atual da produção científica referente ao rompimento da barragem de Fundão (Mariana/MG), caracterizando as publicações quanto ao tema, autoria e instituições de origem, além de destacar outros aspectos relevantes.

A caracterização e a sistematização do quadro de publicações científicas visam contribuir para os avanços nas pesquisas sobre o desastre, evitando-se cenários de fragmentação, dispersão e superposição dos estudos e publicações, bem como lacunas de informações. Esta sinalização pode auxiliar, portanto, o direcionamento das pesquisas por parte de especialistas e instituições interessadas no tema. O trabalho também contribui com todos os leitores/pesquisadores interessados em obter uma fonte integradora dos trabalhos já publicados, facilitando as consultas. 


\section{PROCEDIMENTOS METODOLÓGICOS}

Para a sistematização dos trabalhos publicados acerca do rompimento da barragem de Fundão, foi adotado o recorte temporal de 05/11/2015 (data de ocorrência do desastre) a 15/02/2019, totalizando três anos e três meses. O levantamento bibliográfico tomou como base livros, periódicos e anais de eventos científicos. Contudo, não houve um enfoque em determinado tipo de publicação, tendo a busca por artigos e pesquisas sobre o desastre sido feita a partir do Portal de Periódicos da Capes e da ferramenta de busca do Google Acadêmico.

Durante o levantamento bibliográfico, foram utilizados termos que possibilitassem alusão a trabalhos sobre o desastre ocorrido em Mariana, tais como: barragem de Fundão, Mariana-MG, bacia do rio Doce, rompimento de barragem, Samarco, entre outros. Os termos cunhados foram selecionados com o objetivo de abarcar a multiplicidade dos estudos já realizados, sem que ocorra uma pré-disposição para trabalhos de determinado campo científico.

Além da compilação dos trabalhos, os resultados obtidos permitiram o conhecimento de grupos de pesquisa e instituições de ensino que se destacaram em publicações acerca da temática do rompimento. De modo a atender as diretrizes propostas, os trabalhos analisados foram catalogados no que tange às formações dos autores, temas abordados, instituições e departamentos, dos principais meios de publicação utilizados, além dos recortes espaciais trabalhados. As publicações catalogadas estão disponíveis no Anexo 1.

Para facilitar a visualização dos diferentes aspectos da catalogação dos trabalhos, foram elaborados gráficos com os diferentes agrupamentos que se deseja analisar. A partir desses gráficos, foi possível fornecer um panorama das publicações acerca do desastre durante o período definido.

Posteriormente, foi investigada a diversidade das publicações de acordo com o campo científico, apontando similaridades e discrepâncias. Também foi avaliada a inserção da geografia nos trabalhos publicados, enfatizando as principais abordagens adotadas.

\section{INSTITUIÇÕES ENVOLVIDAS E MEIOS DE PUBLICAÇÃO UTILIZADOS}

A partir da análise da produção científica no período considerado, foi possível expressar e organizar os resultados por categorias, sendo elas: temáticas abordadas, autores, meios de publicação, instituições envolvidas, data de publicação e abrangência espacial.

Foram catalogados e analisados 199 trabalhos científicos, publicados com participação de 91 diferentes instituições. 53 instituições $(58,2 \%)$ se inseriram em apenas um trabalho. O grande número de instituições envolvidas com pesquisas sobre o rompimento da barragem demonstra como o desastre gerou uma grande movimentação na comunidade científica em busca do entendimento de suas causas e consequências, sejam elas ambientais, sociais ou econômicas. Na figura 2 é disposto o 
número de participações de cada instituição em artigos relacionados ao desastre. 75 instituições contribuíram com outras 92 publicações, mas com menos de dois trabalhos cada.

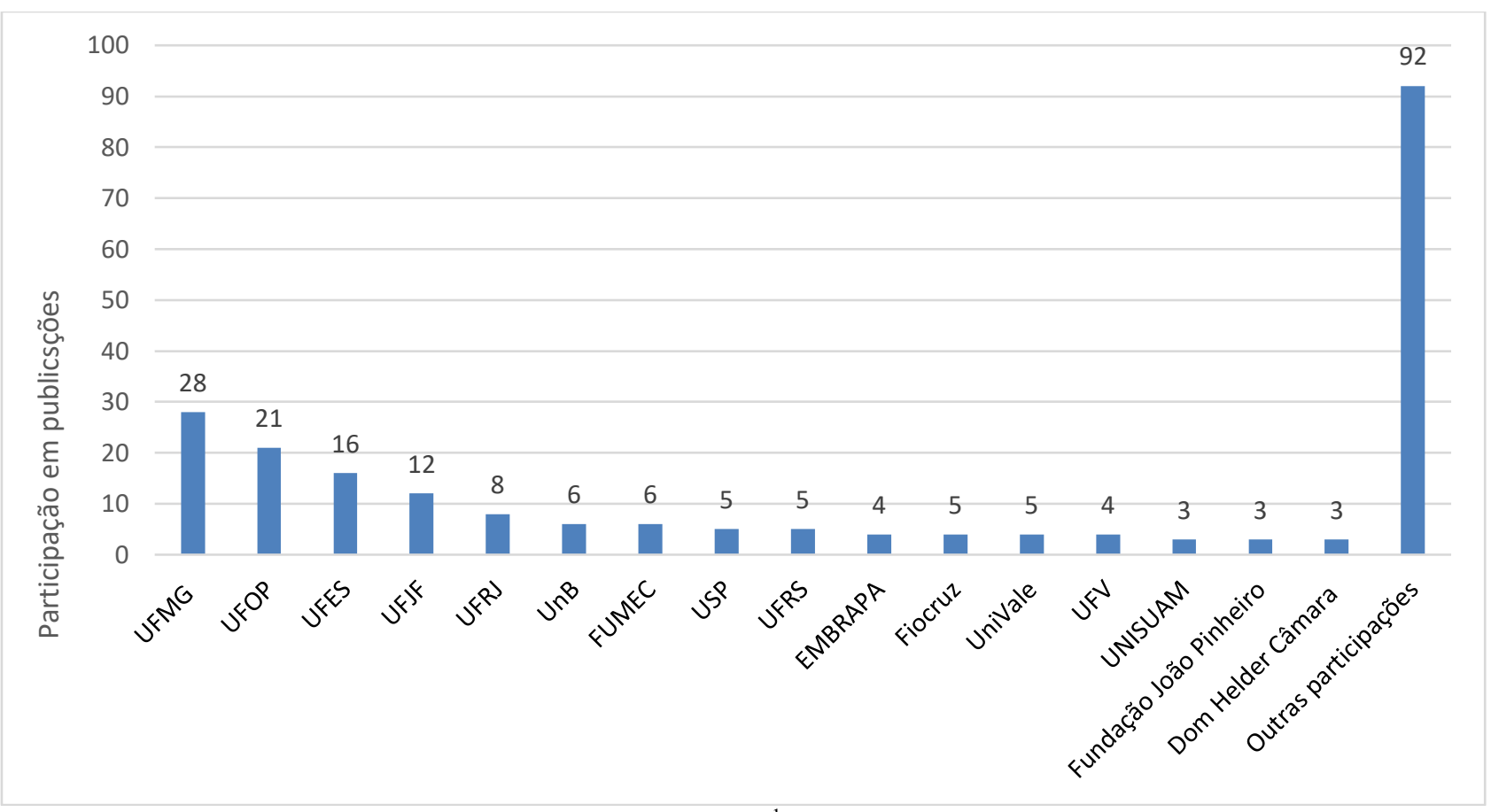

Figura 2 - Relação entre instituições ${ }^{1}$ e participação em publicações.

Dos 199 trabalhos catalogados, 179 deles foram realizados por apenas uma instituição, enquanto 20 trabalhos foram realizados por parcerias entre Instituições. Alguns grupos de pesquisa interinstitucionais mereceram destaque, como o Organon (Núcleo de Estudo, Pesquisa e Extensão em Mobilizações Sociais), o PoEMAS (Grupo Política, Economia, Mineração, Ambiente e Sociedade) e o Homa (Centro de Direitos Humanos e Empresas), com participantes da UERJ, UFJF, UFES, UFOP, UFMG, entre outros.

A UFMG se mostrou como a instituição mais presente em artigos, estando presente em $14,1 \%$ dos trabalhos publicados. Além dela, a UFOP (10,6\%), UFES (8\%) e a UFJF (6\%) deram importantes contribuições para os estudos no desastre do Rio Doce. O destaque dessas instituições pode ser explicado pela sua proximidade com a Bacia do Rio Doce e com o local do rompimento da barragem, além do interesse dos pesquisadores. É perceptível a importância de Universidades Federais, Estaduais e Instituições de Pesquisa do governo (Embrapa e Fiocruz principalmente) na produção científica sobre o desastre.

1 Instituições: Universidade Federal de Minas Gerais (UFMG), Universidade Federal de Ouro Preto (UFOP), Universidade Federal do Espírito Santo (UFES), Universidade Federal de Juiz de Fora (UFJF), Universidade Federal do Rio de Janeiro (UFRJ), Universidade de Brasília (UnB), Fundação Mineira de Educação e Cultura (FUMEC), Universidade de São Paulo (USP), Universidade Federal do Rio Grande do Sul (UFRGS), Empresa Brasileira de Pesquisa Agropecuária (EMBRAPA), Fundação Oswaldo Cruz (Fiocruz), Universidade Vale do Rio Doce (Univale), Universidade Federal de Viçosa (UFV), Centro Universitário Augusto Motta (UNISUAM). 
Já na figura 3, é disposta a forma de publicação dos 199 trabalhos catalogados, distinguidos entre periódicos, anais de eventos científicos, trabalhos de conclusão de curso (TCCs)/dissertações de mestrado, relatórios organizados por instituições/grupos de pesquisa e trabalhos encontrados em livros.

Considerando que os trabalhos de conclusão de curso (TCCs) e dissertações de mestrado 2 são comumente disponibilizadas a partir de um meio comum, associado aos repositórios digitais das universidades de origem, os respectivos trabalhos foram associados a apenas uma forma de publicação.

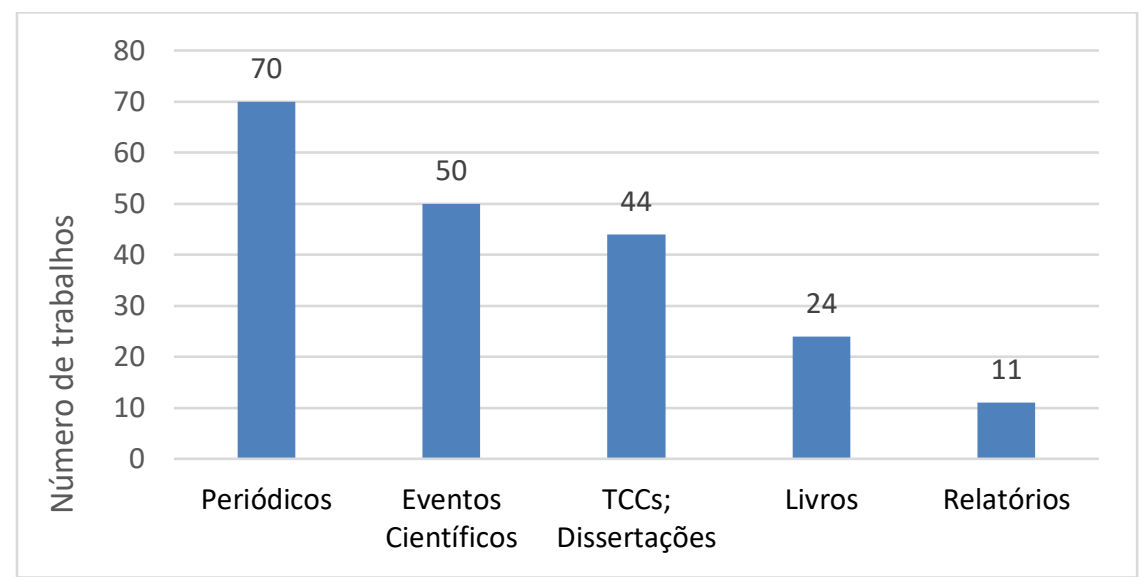

Figura 3 - Meios de publicação dos trabalhos.

Quando se trata dos meios de publicação, 35,1\% dos trabalhos provêm de periódicos, com certa fragmentação dos veículos. A revista Arquivos do Museu de História Natural e Jardim Botânico da UFMG (vinculada ao MHNJB) foi o maior destaque, com oito publicações de textos de especialistas em áreas da geografia, biologia, política, entre outros. As outras 62 publicações estão distribuídas entre diversos periódicos com, no máximo, dois artigos cada.

Os trabalhos e resumos científicos publicados em anais de congressos e simpósios representam 25,1\% das contribuições. Destaque é feito para os eventos organizados pela Sociedade Brasileira de Estudos Interdisciplinares da Comunicação (INTERCOM), como o Congresso Brasileiro de Ciências da Comunicação, aparecendo sete vezes entre os 50 trabalhos apresentados em congressos.

Com $22,1 \%$ das contribuições estão os TCCs (21 trabalhos) e dissertações de mestrado (23 trabalhos). Os cursos e departamentos de origem são bem diversificados, abrangendo variados programas de pós-graduação de diferentes universidades como, por exemplo, os cursos de economia e antropologia da UNB, solos e nutrição em planta da UFV, ciências sociais, jornalismo e serviço

${ }^{2}$ Não foram encontradas teses de doutorado, o que pode ser explicado pelo período de conclusão de um doutorado (em média quatro anos) ser maior do que o período decorrido entre o rompimento da barragem e a realização do presente trabalho. 
social da UFOP, o Centro de Ciências Humanas e Naturais da UFES e psicologia social da Universidade Católica de São Paulo. É perceptível o crescimento da contribuição dos trabalhos publicados por esse meio ao longo dos anos.

Um conjunto de 24 trabalhos se concentra em três livros: "Desastre no Vale do Rio Doce" (MILANEZ; LOSEKANN, 2016), organizado pela PoEMA/Organon, com 12 trabalhos; “Desastre na Bacia do Rio Doce" (LOSEKANN; MAYORGA, 2018), elaborado pela Organização Interinstitucional Mariana Rio Doce e Organon, com sete publicações; e o livro "Mineração, Violência e Resistências" (ZHOURI, 2017), da Associação Brasileira de Antropologia, com quatro publicações. Os dois primeiros se mostram muito completos na abordagem do desastre, com participação de especialistas de diversas áreas. Outro trabalho publicado no livro "Ética, direitos humanos e socioambientalismo" (CALGARO; SIGALLI, 2018) trata de questões éticas sobre as questões socioambientais.

Dentre os relatórios, vale destacar o do "Comitê de especialistas para análise de ruptura de barragem" (MORGENSTERN et al., 2016), que busca definir com exatidão as causas do evento, além de relatórios do IBAMA (2015) e o Encarte Especial sobre a Bacia do Rio Doce, vinculado à Agência Nacional de Águas (ANA, 2016), que descrevem os acontecimentos e impactos diretos do rompimento.

\section{FORMAÇÃO ACADÊMICA DOS AUTORES}

A formação dos autores dos 199 trabalhos levantados se mostrou bem diversificada, evidenciado uma grande multidisciplinaridade nas investigações acerca do rompimento da barragem de Fundão. Foram identificados 447 autores, com destaque para algumas áreas do conhecimento, conforme apresenta a figura 4. O maior número de autores em relação ao número de trabalhos compilados decorre da presença significativa de coautores nas publicações, principalmente da área da biologia.

A figura 4 mostra grande destaque para as áreas de Direito (54 autores), Biologia (45), Comunicação e Jornalismo (39), Engenharia Ambiental (36), Geografia (31), totalizando 45,8\% dos autores. Vale ressaltar a baixa contribuição das áreas de Engenharia Geológica, Geologia, Engenharia de Minas, com apenas um, dois e dois autores cada, respectivamente, mesmo sendo campos do conhecimento diretamente envolvidos com a atividade minerária.

Outro aspecto a ser ressaltado é a participação de autores de 56 diferentes áreas do conhecimento, muitas vezes com equipes multidisciplinares. Outra evidência desse comportamento é a grande quantidade de autores enquadrados em "outros", sendo essas áreas do conhecimento com menos de $1,1 \%$ de participação em relação ao número total. Um exemplo é o trabalho de Soriano et al. (2016), no qual se encontram pesquisadores de áreas como a Geografia, Engenharia Metalúrgica, 
Biologia, Física, Engenharia em Hidrografia e Oceanografia. O caráter multidisciplinar enriquece a discussão sobre o tema e evidencia a preocupação dos pesquisadores em estudar de maneira conjunta os impactos do rompimento da barragem. Não foi possível identificar, no entanto, a formação acadêmica de 10 dos 447 pesquisadores, pois não foram encontrados os respectivos currículos Lattes.

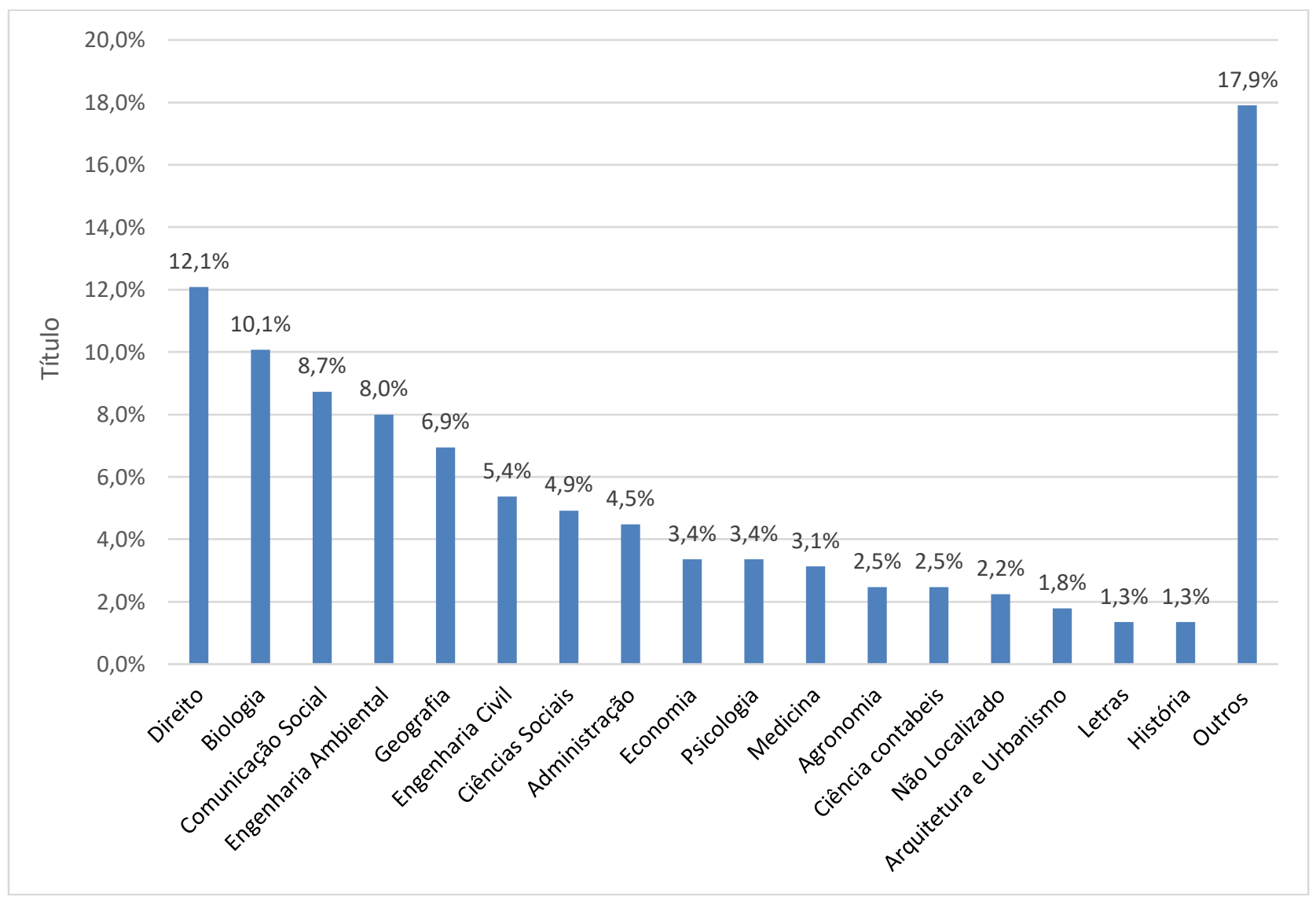

Figura 4 - Relação das áreas de conhecimento e o percentual de autores correspondentes.

\section{TEMAS PESQUISADOS E RECORTES ESPACIAIS ADOTADOS}

Fez-se uma tentativa de aproximar as temáticas pesquisadas a áreas do conhecimento científico para facilitar a visualização dos aspectos mais estudados sobre o rompimento (figura 5). As áreas do conhecimento não possuem dinâmicas independentes umas das outras, mas tentou-se fazer esse esforço de sistematização, levando em conta a formação dos autores, as metodologias adotadas e os objetivos dos trabalhos. Incluiu-se ainda a classe "Interdisciplinar" para aqueles trabalhos que tratam de diversos temas.

A figura 5 evidencia a diversidade de campos da ciência envolvidos nos estudos. Destaca-se a Comunicação, com mais de $15 \%$ do total de publicações, com forte presença da UFOP. A Geografia inclui trabalhos com ênfase na pedologia e em estudos socioambientais. Verifica-se também certo equilíbrio nas publicações das áreas de Ciências Exatas, da Natureza e Humanas. 
Vale ressaltar ainda o número significativo de trabalhos com discussões políticas e jurídicas acerca do tema.

Na figura 6 é possível perceber a concentração de trabalhos publicados sobre a bacia do Rio Doce, particularmente o Alto Rio Doce. Entretanto, a maioria dos trabalhos não adotou um recorte espacial definido.

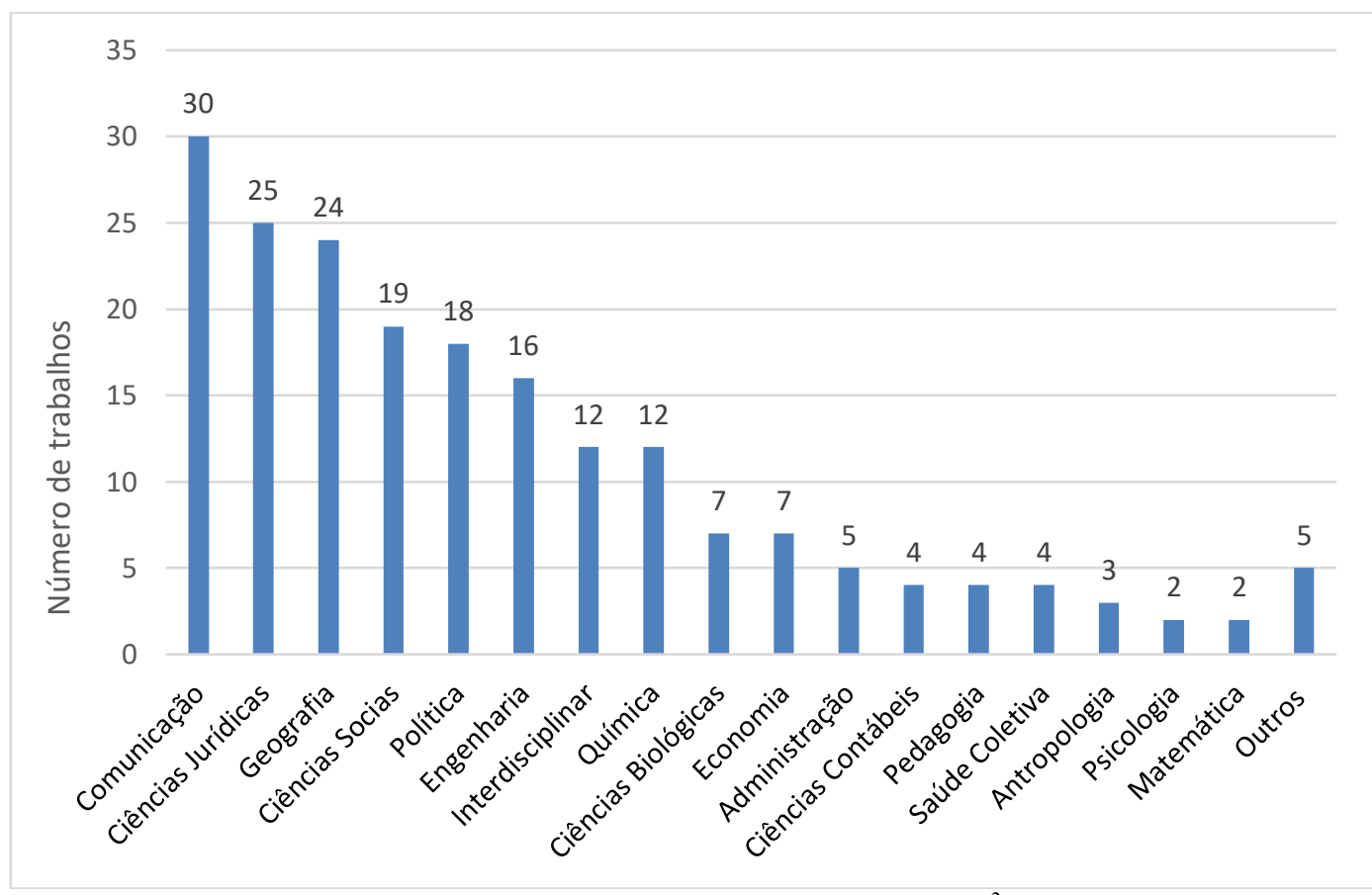

Figura 5 - Relação das temáticas produzidas ${ }^{3}$.

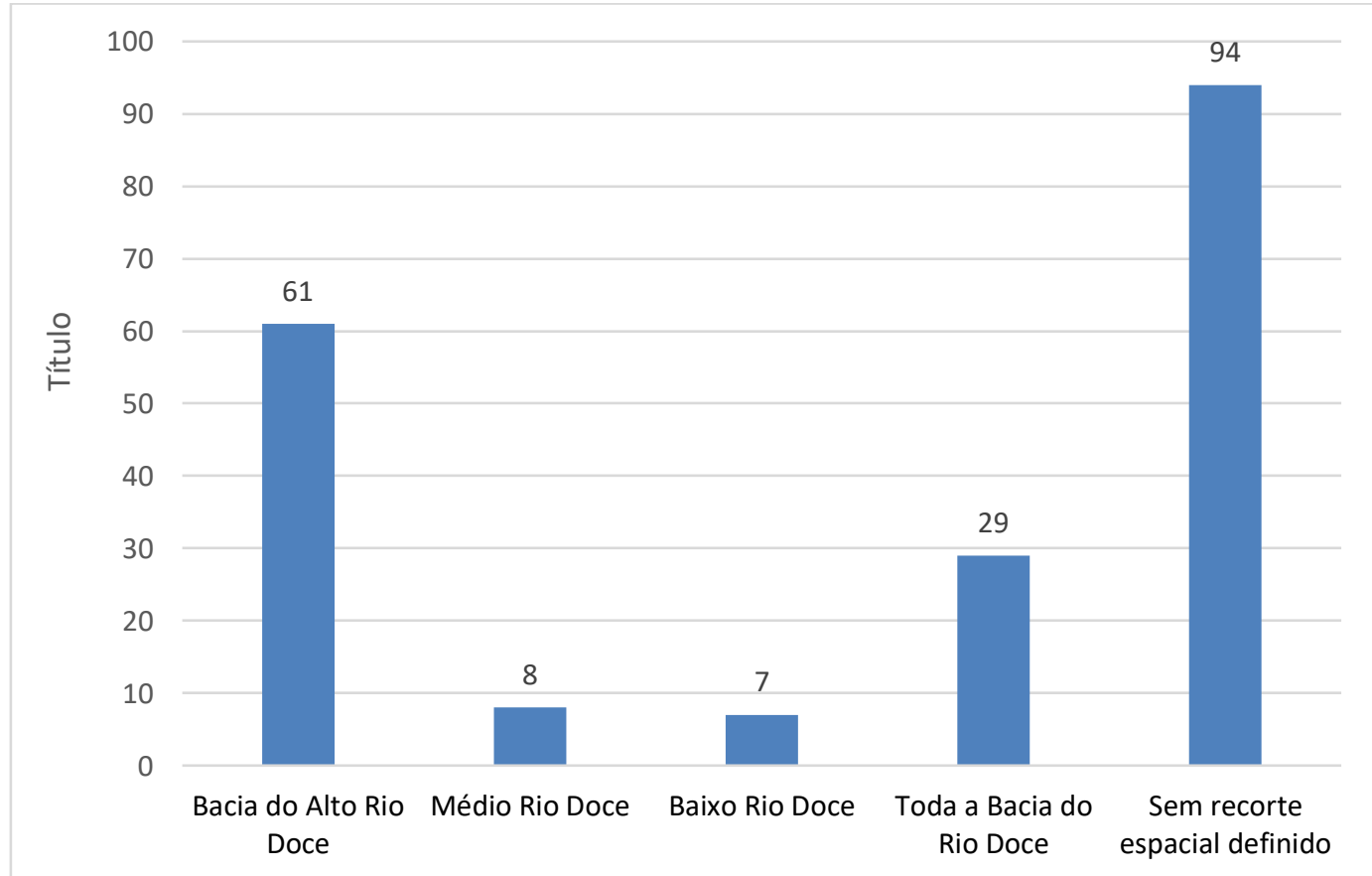

Figura 6 - Número de trabalhos produzidos em cada recorte espacial definido.

${ }^{3} \mathrm{Na}$ categoria "Outros" estão incluídas as temáticas que só tiveram um trabalho publicado. São elas: Geologia, Agronomia, Arquitetura, Filosofia e Museologia. 
A grande quantidade de trabalhos que não trata de um recorte espacial específico pode ser justificada pela rapidez no acesso às informações utilizadas, como as derivadas de reportagens de televisão, jornais e da própria Samarco, além de trabalhos versando sobre as atuações pontuais dos gestores e do que é previsto na legislação para o caso do rompimento. Muitos trabalhos estão relacionados a levantamentos ambientais mais generalizados, e por toda a bacia do Rio Doce, realizados a partir de caravanas de pesquisadores vinculados a universidades (sobretudo federais), associações civis ou órgãos estatais.

Era esperada a relativa concentração de trabalhos na bacia do Alto Rio Doce, pois foi a principal região afetada. Foi nesse trecho onde distritos e povoados como Bento Rodrigues e Paracatu de Baixo foram soterrados pela lama. Além disso, é a área mais próxima de grandes universidades e centros de pesquisa, como a UFMG e a UFOP, responsáveis por muitas publicações. Vale destacar o papel da UFJF, que mesmo estando relativamente mais distante da área afetada, quando comparada com outras universidades, desempenhou relevante papel nas publicações sobre o tema. Além delas, a UFES teve importante papel nos estudos da área do Baixo Rio Doce

Por outro lado, verifica-se a pequena quantidade de trabalhos sobre o Médio e o Baixo Rio Doce, apesar do elevado número de cidades destes segmentos que foram impactadas, como Governador Valadares, Colatina e Regência. Dentre os trabalhos levantados, apenas um estudo abordou o estuário do Rio Doce e nenhum tratou diretamente dos danos causados no ambiente marinho.

Na figura 7 é apresentada a distribuição dos trabalhos quanto à relação entre os campos do conhecimento e os segmentos fluviais ao longo da bacia do rio Doce.

\begin{tabular}{|c|c|c|c|c|c|c|}
\hline Tema & $\begin{array}{l}\text { Toda a bacia } \\
\text { do rio Doce }\end{array}$ & $\begin{array}{l}\text { Bacia do Alto } \\
\text { Rio Doce }\end{array}$ & Médio Rio Doce & Baixo Rio Doce & $\begin{array}{c}\text { Estudos sem } \\
\text { área definida } \\
\text { na bacia }\end{array}$ & TOTAL \\
\hline COMUNICAÇÃO & - & 6 & - & - & 24 & 30 \\
\hline CIÊCIAS JURÍDICAS & 1 & 1 & - & 1 & 22 & 25 \\
\hline GEOGRAFIA & 9 & 14 & - & - & 1 & 24 \\
\hline CIÊNCIAS SOCIAIS & 2 & 8 & - & 4 & 5 & 19 \\
\hline ENGENHARIA & 1 & 9 & 1 & - & 5 & 16 \\
\hline POLÍTICA & 2 & 1 & - & - & 15 & 18 \\
\hline INTERDISCIPLINAR & 5 & 3 & 1 & - & 3 & 12 \\
\hline QUÍMICA & 3 & 7 & 1 & 1 & - & 12 \\
\hline BIOLOGIA & 3 & 1 & 2 & - & 1 & 7 \\
\hline ECONOMIA & 2 & 2 & - & - & 3 & 7 \\
\hline ADMINISTRAÇ $\tilde{A O}$ & - & 3 & - & - & 2 & 5 \\
\hline PEDAGOGIA & - & - & - & - & 4 & 4 \\
\hline SAÚDE PÚBLICA & 1 & 1 & - & 1 & 1 & 4 \\
\hline C. CONTÁBEIS & - & - & - & - & 4 & 4 \\
\hline ANTROPOLOGIA & - & - & 3 & - & - & 3 \\
\hline PSICOLOGIA & - & 2 & - & - & - & 2 \\
\hline MATEMÁTICA & - & - & - & - & 2 & 2 \\
\hline ARQUITETURA & - & 1 & - & - & - & 1 \\
\hline FILOSOFIA & - & - & - & - & 1 & 1 \\
\hline AGRONOMIA & - & - & - & - & 1 & 1 \\
\hline GEOLOGIA & - & 1 & - & - & - & 1 \\
\hline MUSEOLOGIA & - & 1 & - & - & - & 1 \\
\hline TOTAL & 29 & 61 & 8 & 7 & 94 & 199 \\
\hline
\end{tabular}

Figura 7 - Distribuição dos artigos quanto à relação entre os campos do conhecimento e os segmentos fluviais ao longo da bacia do rio Doce. 


\subsection{Publicações abordando toda a Bacia do Rio Doce}

29 trabalhos abordaram toda a bacia do rio Doce, não se restringindo a determinados segmentos. Grande parte deles foi produzido em universidades, com destaque para as cinco publicações da UFMG referentes aos “Arquivos do Museu de História Natural da UFMG”, em seu volume 24.

Quanto aos temas abordados, destacam-se trabalhos na área de Geografia e dos estudos Interdisciplinares, sendo o primeiro com nove e o segundo com cinco publicações. Estes campos do conhecimento abrangem diversos temas e estão associados a técnicas de campo e geotecnologias de espacialização de informações (como o sensoriamento remoto e o geoprocessamento), facilitando o estudo de toda a bacia.

\subsection{Bacia do Alto Rio Doce (incluindo os rios Gualaxo do Norte, do Carmo e afluentes)}

O Alto Rio Doce corresponde ao trecho da bacia à montante da confluência dos rios Doce e Piracicaba. É o segmento mais estudado, com 61 trabalhos publicados, fato justificado pela proximidade com a Barragem de Fundão e, consequentemente, maior ocorrência e intensidade de impactos.

Diversas instituições de ensino e pesquisa deram origem às publicações sobre a bacia do Alto Rio Doce, com destaque para a UFOP (15 trabalhos), UFMG (10), UFES (5) e UFJF (4), além de contribuições da EMBRAPA, principalmente em parceria com a UFMG. As duas primeiras se beneficiam da proximidade do foco do desastre, facilitando as atividades de campo. Outras 30 instituições desenvolveram trabalhos na região.

No tocante às áreas do conhecimento abordadas, desataca-se a Geografia com quatorze publicações, sendo quatro da UFMG. Esta universidade apresentou forte concentração dos trabalhos no Alto Doce, e ausência nos Médio e Baixo trechos da bacia. As áreas de Comunicação (mídias locais), com seis trabalhos, Ciências Sociais, com oito e Engenharia (estudos sobre o rompimento) com nove trabalhos também tiveram grande representatividade de estudos na área. A Química apresentou sete trabalhos, todos relacionados à qualidade das águas fluviais atingidas e propriedades dos pacotes de rejeito.

\subsection{Médio Rio Doce}

Este trecho compreende o segmento entre a confluência do rio Doce com o rio Piracicaba e a divisa entre os estados de Minas Gerais e Espírito Santo. Merecem destaque os trabalhos relacionados à antropologia feitos pela $\mathrm{UnB}$, que tratam do povo Krenak, no parque Sete Salões. Além dele, realizaram-se também estudos sobre a ictiofauna da região (e de uma parte do Baixo Rio 
Doce) e a biodiversidade do Parque Estadual do Rio Doce, sendo essa a maior presença da área de Biologia.

\subsection{Baixo Rio Doce}

O Baixo Rio Doce estende-se da divisa entre Minas Gerais e Espírito Santo até a foz do Rio Doce, sendo foco de apenas oito trabalhos. A área de Ciências Sociais (quatro trabalhos) se destacou, estudando as organizações das populações nessa área e sua interação com as ONG’s e projetos locais. A UFES representa 5 dos 7 trabalhos produzidos, o que pode ser explicado pela proximidade geográfica com o Baixo Rio Doce.

\subsection{Publicações sem recorte espacial específico}

Apesar de todos os trabalhos compilados terem como tema o rompimento da Barragem de Fundão, a maioria (94 publicações) não foca um recorte espacial, tratando de problematizações teóricas sobre a análise da mídia, as questões políticas e institucionais envolvidas ou as implicações jurídicas e legais do rompimento.

As áreas de Comunicação (24 publicações) e Ciências Jurídicas (22) são as mais abordadas, seguidas de abordagens relacionadas à Política (15), Ciências Sociais (5), Engenharias (5), Pedagogia (4) e C. Contábeis (4). Observa-se um predomínio de trabalhos que se relacionam com as áreas humanas e sociais envolvidas no desastre.

A origem das publicações se mostrou novamente muito pulverizada, com destaque para a UFES, com sete trabalhos; para a UFMG, com nove trabalhos, sendo um em parceria com o Instituto Izabela Hendrix, seguida da UFJF, Universidade FUMEC, UFRJ, Dom Helder Câmara e Universidade Federal do Rio Grande do Sul.

\section{O PAPEL DA GEOGRAFIA NO PANORAMA DAS PUBLICAÇÕES}

Dentre os 199 trabalhos catalogados, 24 se referem ao campo da geografia, todos focando a bacia do Alto Rio Doce ou tratando dos efeitos do desastre em toda a bacia. A UFMG com oito trabalhos, sendo dois em parceria com a UFJF (que totaliza 5 trabalhos na área) e a UFRJ (dois trabalhos) possuem papel de destaque na área de Geografia, respondendo por mais da metade das publicações neste campo do conhecimento.

Dentre os diversos temas geográficos abordados, podem ser citados os relativos aos campos da geomorfologia, geografia social, geoprocessamento, pedologia, planejamento territorial, geografia política e geografia ambiental, apresentados na figura 8. 
É nítido que essas áreas apresentam diversas interseções entre si e entre outras áreas do conhecimento. No entanto, fez-se o esforço de separá-las para que a análise desses resultados fosse possível.

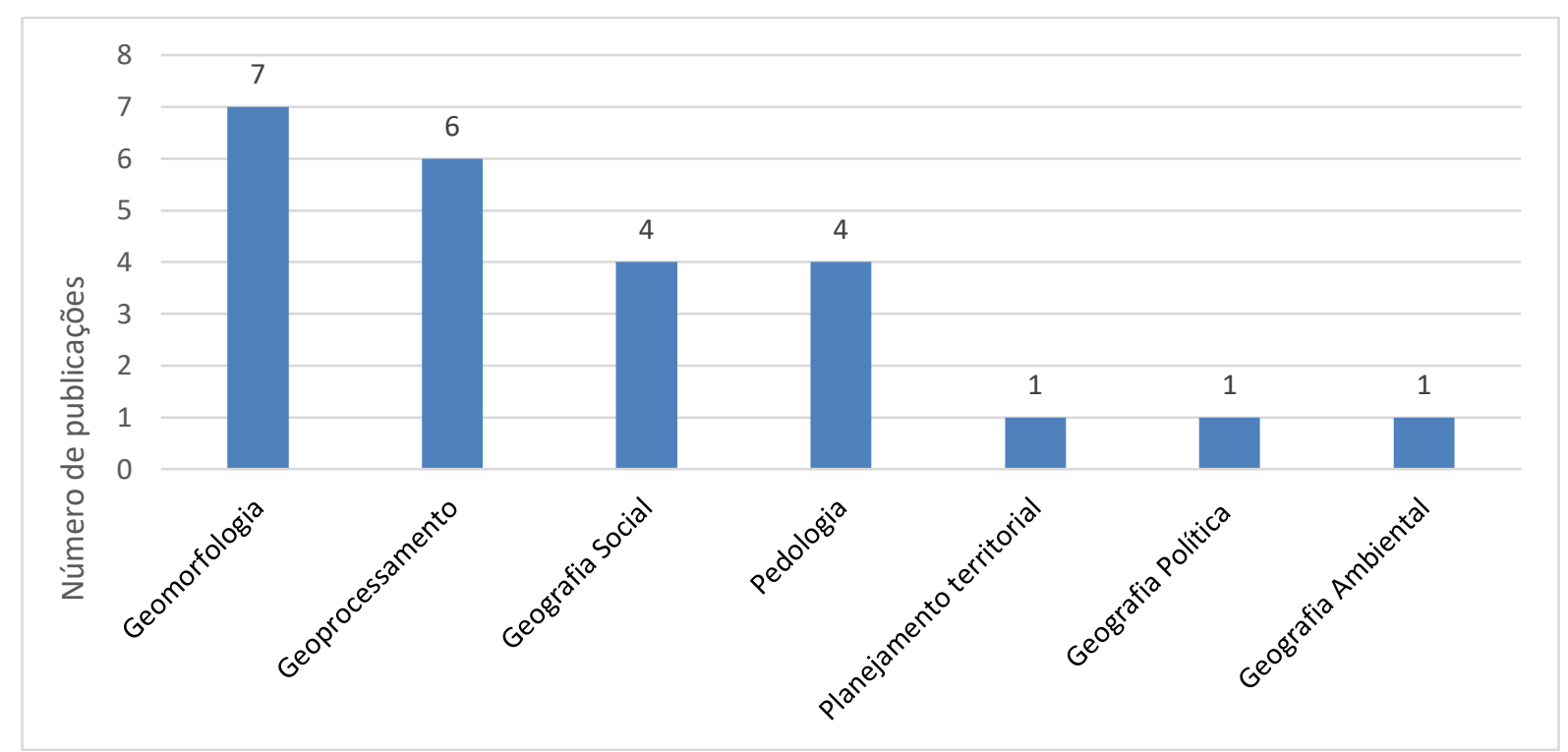

Figura 8 - Número de trabalhos publicados por área da geografia.

Não foram identificados trabalhos focados nos movimentos populacionais ocasionados pelo desastre, sendo esse um dos maiores impactos do rompimento da barragem e de grande interesse da geografia. Além disso, os quatro trabalhos da área de geografia social foram publicados nos 13 meses imediatamente posteriores ao desastre. Há um longo lapso de tempo sem trabalhos realizados sobre a situação dos fatos e problemas sociais das populações em seus territórios depois do início das ações do Estado, dos responsáveis pelo desastre e das próprias organizações populares.

Não foram encontrados trabalhos no campo da Climatologia. Não obstante, os estudos pedológicos e geomorfológicos dialogam com aspectos climáticos, como por exemplo, no papel das chuvas no carreamento do material depositado nas margens fluviais para a calha principal.

Referentes ao estudo dos solos, os estudos pedológicos se concentraram principalmente em Barra Longa e foram elaborados tanto por geógrafos quanto por agrônomos. Esses trabalhos tratam particularmente das propriedades físicas e químicas dos pacotes de rejeitos, bem como de sua suscetibilidade à erosão. Já os estudos sobre geomorfologia (área que aborda a gênese e a dinâmica do relevo) tratam do transporte e deposição de sedimentos fluviais (geomorfologia fluvial), sendo realizados com base principalmente em imagens de satélite da área atingida e nas formas de relevo encontradas na região antes e depois do evento. Somente um trabalho de cunho geomorfológico abrangeu toda a bacia, caracterizando os cursos d'água e as formas de relevo.

O geoprocessamento está representado em um trabalho que busca desenvolver mapas temáticos para as situações ambientais, sociais e econômicas da bacia, além de artigos que 
acompanham a mudança do uso e ocupação do solo a partir de imagens de satélites. Além desses, um artigo propõe uma diferente forma de planejamento territorial, principalmente com participação popular nas decisões acerca das escolhas sobre as atividades econômicas no território. Outro trabalho busca entender as relações de colonialidade ainda persistentes nos tratos com as populações locais, tendo sido definido como geografia política por tratar das relações entre espaço e poder em um definido território. Um trabalho foi ainda definido como "Geografia Ambiental", associada às consequências das ações antrópicas sobre o ambiente natural e transformado. Tal publicação não apresentava especificidades para enquadramento em outra área, sendo definida assim em uma classe geral.

\section{CONSIDERAÇÕES FINAIS}

O panorama bibliográfico a respeito do rompimento da barragem de Fundão pode auxiliar futuras pesquisas sobre o tema, podendo apontar lacunas temáticas e espaciais, além de evitar repetições e sobreposições. Foi possível identificar as instituições de destaque nas publicações: a UFMG, com trabalhos de cunho principalmente geográfico envolvendo geomorfologia, política e pedologia, UFES, com temas diversos, a UFOP, principalmente na área de comunicação e engenharias; e a UFJF, com trabalhos sobre geomorfologia e impactos ambientais (alguns deles em parceria com a UFMG e UFES). A maior parte dos estudos focou a bacia do Alto Rio Doce, havendo lacunas importantes no restante da bacia.

Há uma clara concentração dos trabalhos em temas relacionados às consequências do desastre no quadro fisiográfico da bacia, especialmente nos aspectos hidrológicos, pedológicos e geomorfológicos. Percebe-se a necessidade de investigações que abordem dimensões sociais da população atingida, como os impactos nos usos da água e nos usos da terra, bem como suas conexões. Nesse sentido, futuras pesquisas devem objetivar responder as seguintes indagações: Quais são as possiblidades de usos das águas subterrâneas e fluviais na área atingida? Quais as possibilidades de usos agropecuários nos solos recobertos pela lama de rejeitos? Estas são apenas algumas das questões sem respostas claras. Estas dimensões sociais envolvem questões de saneamento, de saúde pública e de qualidade de vida, assim como aspectos psíquicos e cognitivos relacionados aos traumas do desastre.

\section{AGRADECIMENTOS}

Os autores agradecem ao Conselho Nacional de Desenvolvimento Científico e Tecnológico (CNPq) pelo apoio com a concessão de bolsa de iniciação científica (PIBIC) e bolsa de produtividade em pesquisa. 


\section{REFERÊNCIAS}

ANA - AGÊNCIA NACIONAL DE ÁGUAS. Encarte Especial sobre a Bacia do Rio Doce Rompimento da Barragem em Mariana/MG. Superintendência de Planejamento de Recursos Hídricos (SPR), Brasília, DF, 2016. 50 p.

CALGARO, C.; SINGALLI, I. J (org.). Ética, direitos humanos e socioambientalismo. Caxias do Sul, RS: Educs, 2018. 490 p.

FELIPPE, M. F.; MAGALHAES JÚNIOR, A. P.; MENDES, L. C.; COTA, G. E. M.; CARNEIRO, P. S.; GONTIJO, B. M. Conexões geo-históricas e contemporâneas entre ocupação territorial, degradação ambiental e rarefação hídrica na Bacia do Rio Doce. Geografias, v. 1, n. Especial Vale do Rio Doce, p. 203-222, 2016.

IBAMA - INSTITUTO BRASILEIRO DO MEIO AMBIENTE E DOS RECURSOS NATURAIS RENOVÁVEIS. Laudo Técnico Preliminar - Impactos ambientais decorrentes do desastre envolvendo o rompimento da barragem de Fundão, em Mariana, Minas Gerais. Diretoria de Proteção Ambiental (DIPRO) Coordenação Geral de Emergências Ambientais (CGEMA), Brasília, DF, 2015. $38 \mathrm{p}$.

LOSEKANN, C.; MAYORGA C. (Org.). Desastre na Bacia do Rio Doce: Desafios para a universidade e para instituições estatais. Rio de Janeiro: Folio Digital - Letra e Imagem, 2018. 220 p.

MILANEZ, B.; LOSEKANN, C. (Org.). Desastre no Vale do Rio Doce: Antecedentes, impactos e ações sobre a destruição. Rio de Janeiro: Folio Digital - Letra e Imagem, 2016. 437 p.

MORGENSTERN, N. R.; VICK, S. G.; VIOTTI, C. B.; WATTS, B. D. Comitê de Especialistas para Análise da Ruptura da Barragem de Rejeitos de Fundão - Relatório sobre as Causas Imediatas da Ruptura da Barragem de Fundão. 2016. 83 p. Disponível em: http://fundao investigation.com/wp-content/uploads/general/PR/pt/FinalReport.pdf. Acesso em: 10/07/2018.

NETO, J. O. A.; COTA, G. E. M.; MENDES, L. C.; MAGAlHÃES JÚNIOR, A. P.; FELIPPE, M. F. Considerações sobre o ano hidrológico 2013- 2014 e os seus reflexos nos caudais fluviais da bacia do rio Doce. Geografias, v. 1, n. Especial - Vale do Rio Doce, p. 26-45, 2016.

SORIANO, E.; HOFFMAN, W. A. M.; LONDE, L. de R.; SANTOS, L. B. L.; SOMOZA, R. de L. C. D.. Rompimento de barragens em Mariana (MG): o processo de comunicação de risco de acordo com dados da mídia. Revista Communicare, São Paulo, v. 16, n. 1, p. 52-62. 2016.

VERVLOET, R. J. H. M. A geomorfologia da região de rompimento da barragem da Samarco - Da originalidade da paisagem à paisagem da mineração. In: MILANEZ, B.; LOSEKANN, C. (Org.). Desastre no Vale do Rio Doce: Antecedentes, impactos e ações sobre a destruição. Belo Horizonte: Folio Digital - Letra e Imagem, 2016. p. 91-121.

ZHOURI, A. (Org.). Mineração, violências e resistências: um campo aberto à produção de conhecimento no Brasil. Marabá: Iguana, dez. 2017. 297 p. 


\section{ANEXO 1}

\begin{tabular}{|c|c|c|}
\hline $\begin{array}{l}\text { RECORTE } \\
\text { ESPACIAL }\end{array}$ & REFERÊNCIA & $\begin{array}{l}\text { INSTITUIÇÕES E } \\
\text { ORGANIZAÇÕES } \\
\text { ENVOLVIDAS }\end{array}$ \\
\hline Alto Rio Doce & $\begin{array}{l}\text { PASSOS, F. L. et al. (Des)territórios da mineração: planejamento territorial a partir do } \\
\text { rompimento em Mariana, MG. Cad. Metrop., São Paulo, v. 19, n. 38, p. 269-297, } \\
\text { Apr. } 2017\end{array}$ & $\begin{array}{l}\text { Universidade Federal } \\
\text { de Minas Gerais }\end{array}$ \\
\hline Alto Rio Doce & $\begin{array}{l}\text { MENDES, P. H. A.; MENEZES, W. A. Discurso, cognição e formas de } \\
\text { empoderamento: uma análise do jornal A Sirene. Revista de Estudos da Linguagem, } \\
\text { v. } 24 \text {, p. 1047-1073, } 2016 \text {. }\end{array}$ & $\begin{array}{l}\text { Universidade Federal } \\
\text { de Ouro Preto }\end{array}$ \\
\hline Alto Rio Doce & $\begin{array}{l}\text { DAL GOBBO, E. R.; REBOUÇAS, E. J. Jornal A Sirene e a Retratação do } \\
\text { Cotidiano como Instrumento de Comunicação, Mobilização e Disputa de } \\
\text { Narrativas. In: Congresso Brasileiro de Ciências da Comunicação, 40., 2017, } \\
\text { Curitiba. Anais... Curitiba: INTERCOM, } 2017 .\end{array}$ & $\begin{array}{l}\text { Universidade Federal } \\
\text { do Espírito Santo }\end{array}$ \\
\hline Alto Rio Doce & $\begin{array}{l}\text { AQUINO, M. G. C. et al. A JUSTIÇA AMBIENTAL E A DESTRUIÇÃO DO } \\
\text { SUBDISTRITO DE BENTO.RODRIGUES NO MUNICÍPIO DE MARIANA } \\
\text { MINAS GERAIS - BRASIL. In: Encontro de Pesquisas Ambientais, 9., 2017, Juiz de } \\
\text { Fora. Anais... Juiz de Fora: [s.n], } 2017 .\end{array}$ & $\begin{array}{l}\text { Universidade } \\
\text { Estadual Paulista } \\
\text { Júlio de Mesquita } \\
\text { Filho }\end{array}$ \\
\hline Alto Rio Doce & $\begin{array}{l}\text { VERVLOET, R. J. H M. A geomorfologia da região de rompimento da barragem da } \\
\text { Samarco: a originalidade da paiseagem à paisagem da mineração. In: MILANEZ, B.; } \\
\text { LOSEKANN, C. Desastre no Vale do Rio Doce: Antecedentes, impactos e ações } \\
\text { sobre a destruição. Rio de Janeiro: Folio Digital, 2016. cap. 2, p. 91-124. }\end{array}$ & $\begin{array}{l}\text { Organon - Núcleo de } \\
\text { Estudo, Pesquisa e } \\
\text { Extensão em } \\
\text { Mobilização Social, } \\
\text { da Universidade } \\
\text { Federal } \\
\text { do Espírito Santo } \\
\text { (UFES) }\end{array}$ \\
\hline Alto Rio Doce & $\begin{array}{l}\text { RIBEIRO, L. G. G.; VIEIRA, G. C. O rompimento das barragens no município } \\
\text { mineiro de Mariana: o desastre ambiental e a intervenção do Ministério Público. In: } \\
\text { BRASIL, D. R. (Org.). Direitos humanos, sustentabilidade e proteção ambiental. } \\
\text { 1 ed.Pará de Minas: Virtual Books Editora, 2017, v. 1, p. 121-156. }\end{array}$ & $\begin{array}{l}\text { Escola Superior Dom } \\
\text { Helder Câmara }\end{array}$ \\
\hline Alto Rio Doce & $\begin{array}{l}\text { MENDES, L. C.; FELIPPE, M. F. A geomorfologia do Tecnógeno e suas relações } \\
\text { com o rompimento da Barragem de Fundão (Mariana - MG). Revista de Geografia } \\
\text { PPGEO, Juiz de Fora, v. 6, n. 4, p. 353-362, } 2016\end{array}$ & $\begin{array}{l}\text { Universidade Federal } \\
\text { de Juiz de Fora }\end{array}$ \\
\hline Alto Rio Doce & $\begin{array}{l}\text { MENDES, L. C. Alterações geomorfologicas e danos aos pequenos produtores } \\
\text { rurais atingidos pelo rompimento da Barragem de Fundão na Bacia do Rio do } \\
\text { Carmo-MG. 2018. } 141 \text { f. Dissertação (Mestrado em Geografia). Instituto de Ciências } \\
\text { Humanas, Universidade Federal de Juiz de Fora, Juiz de Fora, 2018. }\end{array}$ & $\begin{array}{l}\text { Universidade Federal } \\
\text { de Juiz de Fora }\end{array}$ \\
\hline Alto Rio Doce & $\begin{array}{l}\text { GOMES BARBOSA, K.; CARVALHO, André Luís . Narrativas do trauma no } \\
\text { jornalismo local: Bento Rodrigues. In: Encontro Nacional da Compós, 25., 2016, } \\
\text { Goiânia. Anais eletrônicos, Goiânia: COMPÓS, 2016. v. 1. p. 1-20. }\end{array}$ & $\begin{array}{l}\text { Universidade Federal } \\
\text { de Ouro Preto }\end{array}$ \\
\hline Alto Rio Doce & $\begin{array}{l}\text { CUNHA, M. A. et al. O caso de estudo 'SAMARCO': Os impactos ambientais, } \\
\text { econômicos e sociais, relativos ao desastre de Mariana. UNISANTA BIOSCIENCE, } \\
\text { v. } 6, \text { p. } 316-327-327,2017 \text {. }\end{array}$ & $\begin{array}{l}\text { Universidade } \\
\text { Metropolitana de } \\
\text { Santos }\end{array}$ \\
\hline Alto Rio Doce & $\begin{array}{l}\text { CRUZ, E. G. M. O atendimento de Saúde Pública para os atingidos do subdistrito } \\
\text { de Bento Rodrigues após o rompimento da barragem de Fundão : transformações } \\
\text { na comunidade por sua voz. 2018. } 76 \text { f. Monografia (Graduação em Serviço Social) } \\
\text { Instituto de Ciências Sociais Aplicadas, Universidade Federal de Ouro Preto, Mariana, } \\
2018 \text {. }\end{array}$ & $\begin{array}{l}\text { Universidade Federal } \\
\text { de Ouro Preto }\end{array}$ \\
\hline Alto Rio Doce & $\begin{array}{l}\text { BARROS, E. O.; PAMBOUKIAN, S. V. D. ANÁLISE DO DESASTRE } \\
\text { ATRAVÉS DA CLASSIFICACAO SUPERVISIONADA DE IMAGENS DE } \\
\text { SENSORIAMENTO REMOTO. Revista Mackenzie de Engenharia e Computação, } \\
\text { São Paulo, v. } 17, \text { n. } 1, \text { p. } 8-26,2017\end{array}$ & $\begin{array}{l}\text { Universidade } \\
\text { Presbiteriana } \\
\text { Mackenzie }\end{array}$ \\
\hline Alto Rio Doce & $\begin{array}{l}\text { SORIANO, E. et al. Rompimento de barragens em Mariana (MG): o processo de } \\
\text { comunicação de risco de acordo com dados da mídia. Revista Communicare, [S.1.], } \\
\text { v. } 16, \text { n. 1, p. 52-62, } 2016 \text {. }\end{array}$ & $\begin{array}{l}\text { Universidade Federal } \\
\text { de São Carlos e } \\
\text { Instituto Nacional de } \\
\text { Pesquisas Espaciais }\end{array}$ \\
\hline Alto Rio Doce & $\begin{array}{l}\text { SILVA, C. V. P. Lama, luto e luta: a vivência dos atingidos pelo desastre da } \\
\text { SAMARCO e a organização popular do Movimento dos Atingidos por Barragens } \\
\text { (MAB) como estratégia de enfrentamento. 2017. Dissertação (Mestrado em } \\
\text { Psicologia Social), Faculdade de Ciências Humanas e da Saúde, Pontifícia } \\
\text { Universidade Católica de São Paulo, São Paulo, } 2017 .\end{array}$ & $\begin{array}{l}\text { Pontífica } \\
\text { Universidade } \\
\text { Católica de São Paulo }\end{array}$ \\
\hline Alto Rio Doce & $\begin{array}{l}\text { SOARES, F. L. S. et al. ANÁLISE MULTITEMPORAL DA ÁREA AFETADA } \\
\text { PÓS-ROMPIMENTO DA BARRAGEM DE FUNDÃO E CARACTERIZAÇÃO DO } \\
\text { REJEITO DE MINÉRIO DE FERRO. In: Congresso ABES/FENASAM, 2017, São } \\
\text { Paulo. Anais... São Paulo: AESANESP, 2017. }\end{array}$ & $\begin{array}{l}\text { Centro Universitário } \\
\text { de Belo Horizonte - } \\
\text { UniBH }\end{array}$ \\
\hline Alto $\mathrm{R}$ & CRUZ, G. S.; DOMINGUES, A. L. ÁREAS IMPACTADAS NA SUB-BACIA DO & Centro Universitário \\
\hline
\end{tabular}




\begin{tabular}{|c|c|c|}
\hline & $\begin{array}{l}\text { RIO GUALAXO DO NORTE: ROMPIMENTO DA BARRAGEM DE FUNDÃO, } \\
\text { MG. Disciplinarum Scientia, Santa Maria, v. 18, n. 2, p. 277-286, } 2017 .\end{array}$ & Franciscano \\
\hline Alto Rio Doce & $\begin{array}{l}\text { CARVALHO, M. S. et al. Concentração de metais no rio Doce em Mariana, Minas } \\
\text { Gerais, Brasil. Acta Brasiliensis, [S.l.], v. 1, p. 37, } 2017 .\end{array}$ & $\begin{array}{l}\text { Centro Universitário } \\
\text { de Formiga }\end{array}$ \\
\hline Alto Rio Doce & $\begin{array}{l}\text { MIRANDA, M. G. et al. Cadê a minha cidade, ou o impacto da tragédia da Samarco } \\
\text { na vida dos moradores de Bento Rodrigues. INTERAÇÕES, Campo Grande-MS, v. } \\
18, \text { n. } 2 \text {, p. } 3-12 \text {, abr./jun. } 2017 \text {. }\end{array}$ & $\begin{array}{l}\text { Centro Universitário } \\
\text { Augusto Motta - } \\
\text { UNISSUAM e } \\
\text { Escola da Magistratura do } \\
\text { Estado do Rio de Janeiro }\end{array}$ \\
\hline Alto Rio Doce & $\begin{array}{l}\text { NOGUEIRA, V. D. C. A situação dos atingidos e atingidas pelo rompimento da } \\
\text { barragem de Fundão em Mariana-MG: Considerações sobre o processo de } \\
\text { reparação. } 2018.74 \text { f. Monografia (Bacharel em Serviço Social). Instituto de Ciências } \\
\text { Sociais Aplicadas, Universidade Federal de Ouro Preto, Mariana, 2018. }\end{array}$ & $\begin{array}{l}\text { Universidade Federal } \\
\text { de Ouro Preto }\end{array}$ \\
\hline Alto Rio Doce & $\begin{array}{l}\text { FONSECA, M. N. E. ANÁLISE DOS MODOS DE FALHA E EFEITOS (FMEA) } \\
\text { PARA AVALIAÇÃO DE UM ACIDENTE EM BARRAGEM DE REJEITOS: } \\
\text { UM EVENTO DE MINERAÇÃO NO BRASIL. 2018. } 80 \text { f. Dissertação (Mestrado } \\
\text { em Engenharia Industrial), Escola Politécnica, Universidade Federal da Bahia, } \\
\text { Salvador, 2018. }\end{array}$ & $\begin{array}{l}\text { Universidade Federal } \\
\text { da Bahia }\end{array}$ \\
\hline Alto Rio Doce & $\begin{array}{l}\text { PEREIRA, M. P. R. et al. ESTABILIDADE DE AGREGADOS DO SOLO EM } \\
\text { DUAS PROPRIEDADES NA ÁREA AFETADA PELO ROMPIMENTO DA } \\
\text { BARRAGEM FUNDÃO EM BARRA LONGA - MG. In: Congresso Nacional de } \\
\text { Meio Ambiente, 14., 2017, Poços de Caldas. Anais... Poços de Caldas: [s.n.], 2017. v. } \\
\text { 9. }\end{array}$ & $\begin{array}{l}\text { Universidade Federal } \\
\text { de Minas Gerais e } \\
\text { EMBRAPA }\end{array}$ \\
\hline Alto Rio Doce & $\begin{array}{l}\text { COSTA, A. M. et al. Qualidade física e química de solos de uma propriedade rural } \\
\text { atingida pelo desastre de Mariana em Minas Gerais. In: Simpósio Mineiro de Ciência } \\
\text { do Solo, 4., 2017, Viçosa. Solos no Espaço e Tempo: Trajetórias e Tendências, } \\
\text { Viçosa: UFV, 2017. v. 1. p. 1-3. }\end{array}$ & $\begin{array}{l}\text { Universidade Federal } \\
\text { de Minas Gerais, } \\
\text { Embrapa e Instituto } \\
\text { Bioatlântica }\end{array}$ \\
\hline Alto Rio Doce & $\begin{array}{l}\text { SANTOS, J. P; et al. SUSCEPTIBILIDADE À EROSÃO NO RIO GUALAXO DO } \\
\text { NORTE - MG. Caminhos da Geografia (UFU. Online), Uberlândia, v. 18, p. 286- } \\
307,2017 \text {. }\end{array}$ & $\begin{array}{l}\text { Universidade Federal } \\
\text { de Minas Gerais e } \\
\text { EMBRAPA }\end{array}$ \\
\hline Alto Rio Doce & $\begin{array}{l}\text { AMARAL, A. C. V.; ALVES, H. S. Uma Nuvem se aproxima da Janela. 2018. } 44 \text { f. } \\
\text { Memorial (Bacharel em Jornalismo), Instituto de Ciências Sociais Aplicadas, } \\
\text { Universidade Federal de Ouro Preto, Mariana, } 2018 \text {. }\end{array}$ & $\begin{array}{l}\text { Universidade Federal } \\
\text { de Ouro Preto }\end{array}$ \\
\hline Alto Rio Doce & $\begin{array}{l}\text { MELLO, J. W. V. et al. Elementos traços em sedimentos e qualidade da água de } \\
\text { rios afetados pelo rompimento da Barragem de Fundão, em Mariana, MG. } 2017 . \\
\text { 44f. Dissertação (Mestrado em Agronomia), Universidade Federal de Viçosa, Viçosa, } \\
2017 .\end{array}$ & $\begin{array}{l}\text { Universidade Federal } \\
\text { de Viçosa }\end{array}$ \\
\hline Alto Rio Doce & $\begin{array}{l}\text { MORGENSTERN, N. R. et al. Comitê de Especialistas para Análise da Ruptura } \\
\text { da Barragem. Nova Iorque: Cleary Gottlieb Steen \& Hamilton, } 2016 .\end{array}$ & $\begin{array}{l}\text { Cleary Gottlieb Steen } \\
\text { \& Hamilton LLP }\end{array}$ \\
\hline Alto Rio Doce & $\begin{array}{l}\text { ÁVILA, B. T. et al. Transformações na morfologia fluvial decorrentes do rompimento } \\
\text { da barragem de Fundão: estudos preliminares. In: Simpósio Brasileiro de Geografia } \\
\text { Física Aplicada, 17., 2017, Campinas. Anais..., Campinas: [s.n], 2017. v. 1. p. 3941- } \\
\text { 3952. }\end{array}$ & $\begin{array}{l}\text { Universidade Federal } \\
\text { de Juiz de Fora }\end{array}$ \\
\hline Alto Rio Doce & $\begin{array}{l}\text { SOUSA, L. S. S. Caso Samarco- Análise dos Impactos Econômico-Financeiro } \\
\text { Após o Desastre. Monografia (Bacharel em Ciências Contábeis) Faculdade de } \\
\text { Administração, Ciências Contábeis e Economia, Universidade Federal de Goiás, } \\
\text { Goiânia, 2017. }\end{array}$ & $\begin{array}{l}\text { Universidade Federal } \\
\text { de Goiás }\end{array}$ \\
\hline Alto Rio Doce & $\begin{array}{l}\text { SILVA, G. F. et al. Análise Espaço-Temporal do desastre ambiental em Mariana a } \\
\text { partir das Geotecnologias. Revista Continentes (UFRRJ), [S.1.], v. 7, n. 13, p. 49-53, } \\
2018 .\end{array}$ & $\begin{array}{l}\text { Universidade Federal } \\
\text { do Rio de Janeiro, } \\
\text { Universidade Federal } \\
\text { Fluminense }\end{array}$ \\
\hline Alto Rio Doce & $\begin{array}{l}\text { PRUDENTE, T. A. et al. L. Os processos de altealmento da barragem de rejeitos de } \\
\text { Fundão, da mineradora Samarco em Mariana (MG), foram os responsáveis pelo } \\
\text { rompimento?. In: Congresso Baiano de Engenharia Sanitária e Ambiental, 4., 2016, } \\
\text { Cruz das Almas. Anais... Cruz das Almas: COBESA, 2016. }\end{array}$ & $\begin{array}{l}\text { Universidade } \\
\text { Salvador }\end{array}$ \\
\hline Alto Rio Doce & $\begin{array}{l}\text { SANTOS, G. R. Técnicas de reconhecimento de padrões para a avaliação de } \\
\text { corpos hídricos afetados por rejeitos do rompimento. 2018. 155f. Dissertação } \\
\text { (Mestrado em Engenharia Ambiental, Meio Ambiente), Universidade Federal de Ouro } \\
\text { Preto, } 2018 \text {. }\end{array}$ & $\begin{array}{l}\text { Universidade Federal } \\
\text { de Ouro Preto }\end{array}$ \\
\hline Alto Rio Doce & $\begin{array}{l}\text { SANTOS, J. P.; JARDIM, H. L. Identificação da expansão da lama por subtração } \\
\text { simples de bandas e análise de componentes principais na barragem de Santarém - } \\
\text { Mariana/MG. In: Simpósio Brasileiro de Geografia Física Aplicada, 17., 2017, } \\
\text { Campinas. Anais..., Campinas: [s.n.], v. 1, } 2017 .\end{array}$ & $\begin{array}{l}\text { Universidade Federal } \\
\text { de Minas Gerais }\end{array}$ \\
\hline Alto Rio Doce & $\begin{array}{l}\text { SOUSA, C. A. JORNAL A SIRENE: mobilização e rememoração das ocorrências } \\
\text { como dispositivo de comunicação. Revista Eletrônica de Ciências Jurídicas, } \\
\text { Ipatinga, v. 1, n. 3, } 2018 \text {. }\end{array}$ & $\begin{array}{l}\text { Faculdade de Direito } \\
\text { de Ipatinga }\end{array}$ \\
\hline Alto Rio Doce & $\begin{array}{l}\text { Secretaria de Meio Ambiente e Desenvolvimento Sustentável - MINAS GERAIS. } \\
\text { Mortandade de peixes na Bacia do Rio Doce após rompimento da barragem da }\end{array}$ & $\begin{array}{l}\text { Secretaria de Mei } \\
\text { Ambiente e }\end{array}$ \\
\hline
\end{tabular}




\begin{tabular}{|c|c|c|}
\hline & Samarco no distrito de Bento Rodrigues (Mariana/MG). Vespasiano, 2016. & $\begin{array}{l}\text { Desenvolvimento } \\
\text { Sustentável }\end{array}$ \\
\hline Alto Rio Doce & $\begin{array}{l}\text { SANTOS, L. M. M.; et al. Qualidade das águas nos rios gualaxo do norte, gualaxo } \\
\text { do sul e do carmo, afluentes do alto rio doce (watu). Metais, metalóides e índice de } \\
\text { qualidade das águas antes e após o rompimento da barragem de rejeitos fundão da } \\
\text { Samarco, Vale/BHP Billliton em Mariana-MG. 2016. Dissertação (Mestrado em } \\
\text { Engenharia Ambiental) - Universidade Federal de Ouro Preto. }\end{array}$ & $\begin{array}{l}\text { Universidade Federal } \\
\text { de Ouro Preto }\end{array}$ \\
\hline Alto Rio Doce & $\begin{array}{l}\text { LOSEKANN, C. "Não foi acidente!" O lugar das emoções na mobilização dos } \\
\text { afetados pela ruptura da barragem de rejeitos da mineradora samarco no Brasil. In: } \\
\text { ZHOURI, A. (Org). Mineração, Violências e Resistências: Um campo aberto à } \\
\text { produção de conhecimentos no Brasil. Marabá (Pará): iGuana, 2018. cap. 2, p. 65-110. }\end{array}$ & $\begin{array}{l}\text { Universidade Federal } \\
\text { do Espírito Santo. } \\
\text { Livro (ABA) }\end{array}$ \\
\hline Alto Rio Doce & $\begin{array}{l}\text { COSTA, A. S. V. et al. Análise das alterações dos parâmetros de qualidade da água do } \\
\text { Rio do Carmo, afluente do Rio Doce, após rompimento da Barragem de Fundão, em } \\
\text { Mariana-MG. Holos Environment, [S.1.], v. 18, n. 2, p. 160-176, } 2018\end{array}$ & $\begin{array}{l}\text { Universidade Federal } \\
\text { dos Vales do } \\
\text { Jequitinhonha e } \\
\text { Mucuri (UFVJM) }\end{array}$ \\
\hline Alto Rio Doce & $\begin{array}{l}\text { MENDES, I. L. F.; ESPINDOLA, G. M. NDVI NO ESTUDO DA ÁREA } \\
\text { IMPACTADA PELO ROMPIMENTO DA BARRAGEM DE FUNDÃO EM } \\
\text { MARIANA-MG. In: Congresso Técnico e Científico da Engenharia e da Agronomia, } \\
\text { 2018, Maceió. Anais... Maceió: CONTECC, } 2018 .\end{array}$ & $\begin{array}{l}\text { Universidade Federal } \\
\text { do Piauí }\end{array}$ \\
\hline Alto Rio Doce & $\begin{array}{l}\text { LIMA JÚNIOR, R. B.; PAIVA, C. F. E. Aspectos geotécnicos fundamentais na } \\
\text { avaliação da estabilidade de barragens. In: Congresso Brasileiro de Geologia de } \\
\text { Engenharia e Ambiental, 16., 2018, São Paulo. Anais... São Paulo: ABGE, } 2018 .\end{array}$ & $\begin{array}{l}\text { Universidade Federal } \\
\text { do ABC }\end{array}$ \\
\hline Alto Rio Doce & $\begin{array}{l}\text { COELHO, P. S. Mulheres do MST em luta pela vida, contra a lama que violenta e } \\
\text { mata. In: Seminário Internacional Fazendo Gênero e Women's Worlds Congress, 11. e } \\
\text { 13., 2017, Florianópolis. Anais Eletrônicos, Florianópolis: [s.n.], } 2017 .\end{array}$ & $\begin{array}{l}\text { Universidade de São } \\
\text { Paulo }\end{array}$ \\
\hline Alto Rio Doce & $\begin{array}{l}\text { SERRANO, A. F. et al. Potencial tóxico de distintos compartimentos geomorfológicos } \\
\text { impactos pelo rompimento da Barragem de Fundão em Mariana (MG). In: Jornada de } \\
\text { Iniciação Científica, 2.; Jornada de Iniciação em Desenvolvimento Tecnológico e } \\
\text { Inovação, 26., 2018, . Anais... Rio de Janeiro: CETEM/MCTIC, 2018. p. 7-11. }\end{array}$ & $\begin{array}{l}\text { Universidade Federal } \\
\text { do Rio de Janeiro }\end{array}$ \\
\hline Alto Rio Doce & $\begin{array}{l}\text { MACHADO, M. S. M. M. Blocos para construção civil feitos com rejeitos } \\
\text { depositados na Barragem de Candonga. 2018. } 75 \text { f. Dissertção (Mestrado em } \\
\text { Engenharia de Materiais), Rede Temática em Engenharia de Materiais, Universidade } \\
\text { Federal de Ouro Preto, Ouro Preto, } 2018 \text {. }\end{array}$ & $\begin{array}{l}\text { Universidade Federal } \\
\text { de Ouro Preto }\end{array}$ \\
\hline Alto Rio Doce & $\begin{array}{l}\text { MILAGRES, A. N. et al. FABRICAÇÃO DE ARGAMASSA MISTA UTILIZANDO } \\
\text { AREIA CONTAMINADA COM RESÍDUOS DE REJEITO DA BARRAGEM DE } \\
\text { FUNDÃO - MARIANA/MG. Revista Uniscientiae, Viçosa, v. 1, n. 2, p. 85-94, } \\
\text { jul./dez. } 2018\end{array}$ & $\begin{array}{l}\text { Faculdade de } \\
\text { Ciências e Tecnologia } \\
\text { de Viçosa }\end{array}$ \\
\hline Alto Rio Doce & $\begin{array}{l}\text { FONSECA, R. P. Tratabilidade da água dos rios Doce e Piranga: parâmetros } \\
\text { otimizados para o projeto de coagulação e floculação. 2018. } 69 \text { f. Monografia } \\
\text { (Graduação em Engenharia Ambiental) - Escola de Minas, Universidade Federal de } \\
\text { Ouro Preto, Ouro Preto, } 2018 .\end{array}$ & $\begin{array}{l}\text { Universidade Federal } \\
\text { de Ouro Preto }\end{array}$ \\
\hline Alto Rio Doce & $\begin{array}{l}\text { ROSA, D. D.; BARRETO, L. C.; MAYORGA, C. Metodologias participativas como } \\
\text { estratégias de ensino e intervenção em contextos de desastres.In: LOSEKANN, C.; } \\
\text { MAYORGA, C (Org). Desastre na Bacia do Rio Doce: desafios para a universidade } \\
\text { e para instituições estatais. Rio de Janeiro: Folio Digital Letra e Imagem, 2018. cap. 4, } \\
\text { p. } 97-120 .\end{array}$ & $\begin{array}{l}\text { Ensino, Pesquisa e } \\
\text { Extensão Conexões } \\
\text { de Saberes } \\
\text { (Universidade } \\
\text { Federal de Minas } \\
\text { Gerais); Observatório } \\
\text { Interinstitucional } \\
\text { Mariana-Rio Doce, } \\
\text { UFMG }\end{array}$ \\
\hline Alto Rio Doce & $\begin{array}{l}\text { REIS, M. R. C.; SANTOS, M. E. P. O desastre em Mariana (MG): expressão da luta } \\
\text { pela garantia dos direitos humanos. In: Seminário Científico da FACIG, 2., 2016, } \\
\text { Manhuaçu. Anais... Manhuaçu: FACIG, 2016. }\end{array}$ & $\begin{array}{l}\text { Universidade Federal } \\
\text { de Juiz de Fora }\end{array}$ \\
\hline Alto Rio Doce & $\begin{array}{l}\text { LVA, G. A. Refugiados de Bento Rodrigues: estudo fenomenológico sobre o } \\
\text { desastre de Mariana, MG. 2016. } 30 \text { f. Monografia (Graduação em Administração) - } \\
\text { Instituto de Ciências Sociais Aplicadas, Universidade Federal de Ouro Preto, Mariana, } \\
\text { 2016. }\end{array}$ & $\begin{array}{l}\text { Universidade Federal } \\
\text { de Ouro Preto }\end{array}$ \\
\hline Alto Rio Doce & $\begin{array}{l}\text { SARAIVA, C.; et al. Trabalho e Memória como categorias de reconstrução: } \\
\text { Observatório Interinstitucional da Tragédia Mariana - Rio Doce na UFOP. In: } \\
\text { LOSEKANN, C.; MAYORGA, C. (Org.). Desastre na Bacia do Rio Doce: desafios } \\
\text { para a universidade e para instituições estatais. Rio de Janeiro: Folio Digital Letra e } \\
\text { Imagem, 2018. cap. 3, p. 71-96. }\end{array}$ & $\begin{array}{l}\text { Observatório } \\
\text { Interinstitucional da } \\
\text { Tragédia Mariana - } \\
\text { Rio Doce na } \\
\text { Universidade Federal } \\
\text { de Ouro Preto } \\
\end{array}$ \\
\hline Alto Rio Doce & $\begin{array}{l}\text { PAAZ, C.; SOUZA, L. R. As consequências sociais do rompimento da Barragem de } \\
\text { Fundão em Mariana: uma análise por meio de pesquisa de campo. REVISTA } \\
\text { CATALANA DE DIREITO AMBIENTAL, [S.1.], v. 9, n. 2, p. 1-50, } 2018 .\end{array}$ & $\begin{array}{l}\text { Universidade } \\
\text { Regional de } \\
\text { Blumenau } \\
\end{array}$ \\
\hline Alto Rio Doce & LIMA, G. N.; OLIVEIRA, E. G. Cozinha, café, prosa e cuidado: rupturas e & Sem vínculo direto. \\
\hline
\end{tabular}




\begin{tabular}{|c|c|c|}
\hline & $\begin{array}{l}\text { permanências no cotidiano de mulheres da comunidade atingida de Paracatu de Baixo, } \\
\text { Mariana. Tessituras, Pelotas, v. } 6 \text {, n. } 2 \text {, p. } 76-109 \text {, jul./dez. } 2018 \text {. }\end{array}$ & \\
\hline Alto Rio Doce & $\begin{array}{l}\text { JUNIOR, A. A. S. J; BRANDR, W. Os Estudos de paleosismicidade como ferramenta } \\
\text { de gestão de riscos: evidências, literatura e futuro. Arquivos do Museu de História } \\
\text { Natural e Jardim Botânico - UFMG, Belo Horizonte, v. 24, n. 1/2. p. 44-62, } 2015 .\end{array}$ & $\begin{array}{l}\text { Universidade Federal } \\
\text { de Ouro Preto e } \\
\text { Universidade Federal } \\
\text { de Minas Gerais }\end{array}$ \\
\hline Alto Rio Doce & $\begin{array}{l}\text { XAVIER, T. P. PAISAGENS QUE SE TRANSFORMAM: UM ESTUDO DOS } \\
\text { IMPACTOS CAUSADOS NA PAISAGEM DE BENTO RODRIGUES APÓS O } \\
\text { ROMPIMENTO DA BARRAGEM DA SAMARCO EM MARIANA-MG. In: } 4^{\circ} \\
\text { Colóquio Ibero-Americano Paisagem Cultural, Patrimônio e Projeto - Desafios e } \\
\text { perspectivas, Belo Horizonte/ MG. } 2016 .\end{array}$ & $\begin{array}{l}\text { Universidade Federal } \\
\text { de Minas Gerais }\end{array}$ \\
\hline Alto Rio Doce & $\begin{array}{l}\text { ARCURI, M.; LAIA, P. O.; SUÑER, R. Territórios e patrimônios na lama das } \\
\text { negociações: desafios para a museologia comunitária na Barragem de Fundão. } \\
\text { Arquivos do Museu de História Natural e Jardim Botânico - UFMG, Belo } \\
\text { Horizonte, v. 24, n. 1/2, p. 209-244, } 2015 \text {. }\end{array}$ & $\begin{array}{l}\text { Universidade de São } \\
\text { Paulo }\end{array}$ \\
\hline Alto Rio Doce & $\begin{array}{l}\text { BORTOLON, P. A Samarco e o desastre de Mariana (MG): um estudo em } \\
\text { representações sociais a partir da perspectiva dos ex-funcionários da Samarco. } 2018 . \\
145 \text { f.Dissertação (Mestre em Administração). Centro de Ciências Jurídicas e } \\
\text { Econômicas, Universidade Federal do Espírito Santo, Vitória, 2018. }\end{array}$ & $\begin{array}{l}\text { Universidade Federal } \\
\text { do Espírito Santo }\end{array}$ \\
\hline Alto Rio Doce & $\begin{array}{l}\text { SILVA, J. F. DA ESPECIALIZAÇÃO PRODUTIVA AO ROMPIMENTO DA } \\
\text { BARRAGEM DE FUNDÃO: UMA ANÁLISE DA RESILIÊNCIA ECONÔMICA } \\
\text { PARA O MUNICÍPIO DE MARIANA/MG. 2018. 129f. Dissertação (Mestrado em } \\
\text { Economia Aplicada), Instituto de Ciências Sociais Aplicadas, Universidade Federal de } \\
\text { Ouro Preto, Mariana, 2018. }\end{array}$ & $\begin{array}{l}\text { Universidade Federal } \\
\text { de Ouro Preto }\end{array}$ \\
\hline Alto Rio Doce & $\begin{array}{l}\text { GUIMARÃES, I. M. Gênero e Trabalho: um estudo de caso sobre as mulheres e o } \\
\text { mercado de trabalho na Organização Cáritas (Mariana-MG). 2018. } 46 \text { f. Monografia } \\
\text { (Graduação em Administração) - Instituto de Ciências Sociais Aplicadas, } \\
\text { Universidade Federal de Ouro Preto, Mariana, 2018. }\end{array}$ & $\begin{array}{l}\text { Universidade Federal } \\
\text { de Ouro Preto }\end{array}$ \\
\hline Alto Rio Doce & $\begin{array}{l}\text { MARTINS, J. J. Mercado imobiliário: um estudo da percepção dos empresários do } \\
\text { segmento imobiliário na cidade de Mariana - MG. 2018. } 34 \text { f. Monografia (Graduação } \\
\text { em Administração) - Instituto de Ciências Sociais Aplicadas, Universidade Federal de } \\
\text { Ouro Preto, Mariana, 2018. }\end{array}$ & $\begin{array}{l}\text { Universidade Federal } \\
\text { de Ouro Preto }\end{array}$ \\
\hline Alto Rio Doce & $\begin{array}{l}\text { INSTITUTO DE PESQUISA ECONÔMICA APLICADA. Os pescadores da bacia } \\
\text { do Rio Doce: subsídios para a mitigação dos impactos socioambientais do desastre da } \\
\text { Samarco em Mariana, Minas Gerais. Brasília, } 2016 \text {. }\end{array}$ & $\begin{array}{l}\text { Instituto de Pesquisa } \\
\text { Econômica Aplicada }\end{array}$ \\
\hline $\begin{array}{l}\text { Alto-Médio Rio } \\
\text { Doce }\end{array}$ & $\begin{array}{l}\text { GOMES, V. M. C. Análise dos Impactos do desastre da Samarco em Minas Gerais, na } \\
\text { conjuntura Socioeconômica dos pescadores da Bacia do Rio Doce. In: Simpósio } \\
\text { Acadêmico de Engenharia de Produção, 4., 2018, Governador Valadares. Anais... } \\
\text { Governador Valadares: IFMG, } 2018 .\end{array}$ & $\begin{array}{l}\text { Instituto Federal de } \\
\text { Minas Gerais }\end{array}$ \\
\hline $\begin{array}{l}\text { Alto-Médio Rio } \\
\text { Doce }\end{array}$ & $\begin{array}{l}\text { BORGES, A. C; PEREIRA, M. A. ANÁLISE COMPARATIVA DA QUALIDADE } \\
\text { DA ÁGUA NA BACIA DO RIO DOCE APÓS ROMPIMENTO DA BARRAGEM } \\
\text { DO FUNDÃO, MARIANA - MINAS GERAIS. Revista Científica Semana } \\
\text { Acadêmica, Fortaleza, } 2016, \text { n. } 4,2016 .\end{array}$ & $\begin{array}{l}\text { Centro Universitário } \\
\text { Una - BH }\end{array}$ \\
\hline $\begin{array}{l}\text { Alto-Médio Rio } \\
\text { Doce }\end{array}$ & $\begin{array}{l}\text { GUIMARÃES, J. I. et al. Impacto do Rompimento de Uma Barragem de Rejeitos de } \\
\text { Ferro Sobre a Qualidade das Águas Superificiais. Estudo de Caso: Bacia do Rio Doce. } \\
\text { In: Simpósio Brasileiro de Recursos Hídricos, 22., 2017, Florianópolis. Anais... } \\
\text { Florianópolis: ABRH, } 2017 .\end{array}$ & $\begin{array}{l}\text { Universidade Federal } \\
\text { de Minas Gerais }\end{array}$ \\
\hline Baixo Rio Doce & $\begin{array}{l}\text { ROCHA, E. M. et al. Impacto do rompimento da barragem em Mariana-MG na saúde } \\
\text { da população ribeirinha da cidade de Colatina-ES. Tempus: Actas de Saúde } \\
\text { Coletiva, Brasília, v. } 10 \text {, p. } 31,2016 \text {. }\end{array}$ & $\begin{array}{l}\text { Centro Universitário } \\
\text { do Espírito Santo - } \\
\text { UNESC }\end{array}$ \\
\hline Baixo Rio Doce & $\begin{array}{l}\text { XAVIER, E. M. Representações sociais sobre os pescadores em Regência - } \\
\text { Linhares/ES: No contexto das ações do programa de ressarcimento e indenização dos } \\
\text { impactados pelo desastre da barragem de Fundão. In: Seminário de Ciências Sociais, } \\
\text { 2., 2017, Vitória-ES. Anais... Vitória: UFES, 2017. }\end{array}$ & $\begin{array}{l}\text { Universidade federal } \\
\text { do Espírito Santo }\end{array}$ \\
\hline Baixo Rio Doce & $\begin{array}{l}\text { ROMERO, Thais Bastos; et al. GEOQUÍMICA DE SEDIMENTOS DO } \\
\text { ESTUÁRIO DO RIO DOCE (ES) APÓS ROMPIMENTO DA BARRAGEM EM } \\
\text { MARIANA (MG). In: Encontro de Pesquisa e Pós-Graduação, 9., 2016, Fortaleza. } \\
\text { Anais... Fortaleza: [s.n], v. 1, } 2016 .\end{array}$ & $\begin{array}{l}\text { Universidade Federal } \\
\text { do Ceará }\end{array}$ \\
\hline Baixo Rio Doce & $\begin{array}{l}\text { SILVA, B. J. A lama que rolou de cima. 2018. Dissertação (Mestre em Ciências } \\
\text { Sociais), Centro de Ciências Humanas e Naturais, Universidade Federal do Espírito } \\
\text { Santo, Vitória, } 2018 .\end{array}$ & $\begin{array}{l}\text { Universidade Federal } \\
\text { do Espírito Santo }\end{array}$ \\
\hline Baixo Rio Doce & $\begin{array}{l}\text { DIAS, T. H. Análise da pré-execução do Programa de Indenização Mediada e a tutela } \\
\text { adequada dos direitos coletivos lato sensu. In: Congresso de Processo Civil } \\
\text { Internacional, 2., 2017, Vitória. Anais... Vitória: [s.n], } 2017 .\end{array}$ & $\begin{array}{l}\text { Universidade Federal } \\
\text { do Espírito Santo }\end{array}$ \\
\hline Baixo Rio Doce & $\begin{array}{l}\text { CREADO, E. S. J. et al. Modos de olhar, contar e viver: a chegada da "lama da } \\
\text { samarco" na foz do Rio Doce, em Regência Augusta (ES) como um evento crítico. In: } \\
\text { MILANEZ, B.; LOSEKANN, C (Org). Desastre no Vale do Rio Doce: Antecedentes, } \\
\text { impactos e ações sobre a destruição. Rio de Janeiro: Folio Digital, 2016. cap. 6, p. }\end{array}$ & $\begin{array}{l}\text { Grupo de Estudos e } \\
\text { Pesquisas em } \\
\text { Populações } \\
\text { Pesqueiras e }\end{array}$ \\
\hline
\end{tabular}




\begin{tabular}{|c|c|c|}
\hline & $233-266$ & $\begin{array}{l}\text { Desenvolvimento no } \\
\text { ES, Universidade } \\
\text { Federal do Espírito } \\
\text { Santo. Livro UFES }\end{array}$ \\
\hline Baixo Rio Doce & $\begin{array}{l}\text { LOSEKANN, C. Para pensar a pesquisa-extensão - Apresentando a Arena Itinerante } \\
\text { Grandes Empreendimentos e o Desastre da Samarco realizada com os atingidos pelo } \\
\text { desastre. In: LOSEKANN, C.; MAYORGA, C. (Org.). Desastre na Bacia do Rio } \\
\text { Doce: desafios para a universidade e para instituições estatais. Rio de Janeiro: Folio } \\
\text { Digital Letra e Imagem, 2018. cap. 1, p. 11-44. }\end{array}$ & $\begin{array}{l}\text { Universidade Federal } \\
\text { do Espírito Santo }\end{array}$ \\
\hline Médio Rio Doce & $\begin{array}{l}\text { RODRIGUES, D. R. A MARGEM, À ESQUERDA E AO CONTRÁRIO - A } \\
\text { MORTE DO UATU. 2017. } 64 \text { f. Monografia (Bacharel em Ciências Sociais). } \\
\text { Departamento de Antropologia, Universidade de Brasília, Brasília, 2017. }\end{array}$ & $\begin{array}{l}\text { Universidade de } \\
\text { Brasília }\end{array}$ \\
\hline Médio Rio Doce & $\begin{array}{l}\text { FIOROTT, T. H. A morte do Uatu - impactos do desastre da Samarco/Vale/BHP } \\
\text { sobre a sustentabilidade do povo Krenak. Dissertação (Mestrado em } \\
\text { Desenvolvimento Sustentável). } 2017.158 \text { f. Centro de Desenvolvimento Sustentável, } \\
\text { Universidade de Brasília, Brasília, } 2017 .\end{array}$ & $\begin{array}{l}\text { Universidade de } \\
\text { Brasília }\end{array}$ \\
\hline Médio Rio Doce & $\begin{array}{l}\text { FERNANDES, F. A. et al. A relação entre o desastre da Samarco e uma associação de } \\
\text { pescadores amadores. In: Simpósio de Meio Ambiente, 10., 2017, Viçosa Anais de } \\
\text { resumos expandidos [recurso eletrônico] ...., Viçosa (MG): [s.n.], 2017, p. 3-7 }\end{array}$ & $\begin{array}{l}\text { Universidade Vale do } \\
\text { Rio Doce, Instituto } \\
\text { Federal de Minas } \\
\text { Gerais }\end{array}$ \\
\hline Médio Rio Doce & $\begin{array}{l}\text { ESPINDOLA, H. S. et al. Desastre da Samarco no Brasil: desafios para a conservação } \\
\text { da biodiversidade. Journal of Social, Technological and Environmental Science, } \\
\text { [S.l.], v. 5, n. 3, p. } 72-100,2016 \text {. }\end{array}$ & $\begin{array}{l}\text { Universidade Vale do } \\
\text { Rio Doce, PPG } \\
\text { Gestão Integrada }\end{array}$ \\
\hline Médio Rio Doce & $\begin{array}{l}\text { MAIA, L. C.; PEREIRA, A. R. IMPACTOS NO ABASTECIMENTO DE ÁGUA } \\
\text { DECORRENTES DO ROMPIMENTO DA BARRAGEM DE FUNDÃO: ESTUDO } \\
\text { DE CASO DE GOVERNADOR VALADARES. In: Congresso ABES/FENASAM, } \\
\text { 2017, São Paulo. Anais... São Paulo: AESANESP, } 2017 .\end{array}$ & $\begin{array}{l}\text { Universidade Federal } \\
\text { de Ouro Preto }\end{array}$ \\
\hline Médio Rio Doce & $\begin{array}{l}\text { FIOROTT, T. H.; ZANETI, I. C. B. B.Tragédia do Povo Krenak pela Morte do Rio } \\
\text { Doce / Uatu, no Desastre da Samarco / Vale/ BHP, Brasil. Fronteiras: Journal of } \\
\text { Social, Technological and Environmental Science, [S.1.], v. 6, p. 127, } 2017 .\end{array}$ & $\begin{array}{l}\text { Universidade de } \\
\text { Brasília }\end{array}$ \\
\hline Médio Rio Doce & $\begin{array}{l}\text { SARTORI, E.; et al. USO DA ABNT NBR 15088/2011 PARA A AVALIAÇÃO DA } \\
\text { TOXICIDADE DA ÁGUA DO RIO DOCE E DO POTENCIAL DE } \\
\text { ACUMULAÇÃO DE METAIS EM PEIXES. Revista UniVap, São José dos Campos, } \\
\text { v. } 22, \text { p. } 645,2017 .\end{array}$ & $\begin{array}{l}\text { Universidade } \\
\text { Estadual do Norte } \\
\text { Fluminense Darcy } \\
\text { Ribeiro, Universidade } \\
\text { Federal do Espírtio } \\
\text { Santo } \\
\end{array}$ \\
\hline $\begin{array}{l}\text { Médio-Baixo Rio } \\
\text { Doce }\end{array}$ & $\begin{array}{l}\text { GUIMARÃES, N. C. Avaliação do bioacúmulo de metais e estresse oxidativo em } \\
\text { ratos tratados cronicamente com água do Rio Doce após rompimento da } \\
\text { Barragem de Fundão. 2017. } 86 \text { f. Dissertação (Mestrado em Ciências } \\
\text { Farmacêuticas), Faculdade de Ciências da Saúde, Universidade de Brasília, Brasília. }\end{array}$ & $\begin{array}{l}\text { Universidade de } \\
\text { Brasília }\end{array}$ \\
\hline $\begin{array}{l}\text { Não trata de um } \\
\text { local específico }\end{array}$ & $\begin{array}{l}\text { MILANEZ, B.; LOSEKANN, C. Considerações finais: desafios para o Rio Doce e } \\
\text { para o debate sobre o modelo mineral brasileiro. In: MILANEZ, B.; LOSEKANN, C. } \\
\text { (Org.). Desastre no Vale do Rio Doce: Antecedentes, impactos e ações sobre a } \\
\text { destruição. Rio de Janeiro: Folio Digital, 2016. cap. 3, p. 401-428. }\end{array}$ & $\begin{array}{l}\text { PoEMAS } \\
\text { (Universidade } \\
\text { Federal de Juiz de } \\
\text { Fora), Organon } \\
\text { (Universidade } \\
\text { Federal do Espírito } \\
\text { Santo). Livro } \\
\text { Universidade Federal } \\
\text { do Espírito Santo }\end{array}$ \\
\hline $\begin{array}{l}\text { Não trata de um } \\
\text { local específico }\end{array}$ & $\begin{array}{l}\text { MILANEZ, B. et al. Desafios para uma prática científica crítica diante do desastre na } \\
\text { bacia do Rio Doce. In: LOSEKANN, C.; MAYORGA, C. (Org.). Desastre na Bacia } \\
\text { do Rio Doce: desafios para a universidade e para instituições estatais. Rio de Janeiro: } \\
\text { Folio Digital Letra e Imagem, 2018. cap. 5, p. 121-146. }\end{array}$ & $\begin{array}{l}\text { Grupo de Estudos e } \\
\text { Pesquisas } \\
\text { Socioambientais, da } \\
\text { UFOP (Universidade } \\
\text { Federal de Ouro } \\
\text { Preto); Homa - } \\
\text { Centro de Direitos } \\
\text { Humanos e } \\
\text { Empresas; Organon - } \\
\text { Núcleo de Estudo, } \\
\text { Pesquisa e Extensão } \\
\text { em Mobilização } \\
\text { Social, da } \\
\text { Universidade Federal } \\
\text { do Espírito Santo } \\
\text { (Universidade } \\
\text { Federal do Espírito } \\
\text { Santo) e PoEMAs - } \\
\text { Grupo Política, } \\
\text { Economia, } \\
\end{array}$ \\
\hline
\end{tabular}




\begin{tabular}{|c|c|c|}
\hline & & $\begin{array}{l}\text { Mineração, Ambiente } \\
\text { e Sociedade }\end{array}$ \\
\hline $\begin{array}{l}\text { Não trata de um } \\
\text { local específico }\end{array}$ & $\begin{array}{l}\text { SANTOS, C. C. O. ; et al. A não fiscalização dos órgãos governamentais e a tragédia } \\
\text { da Samarco. LexCult, Rio de Janeiro, v. 2, n. 1, p. 110-129, jan./abr. } 2018\end{array}$ & $\begin{array}{l}\text { Sociedade Unificada } \\
\text { de Ensino Augusto } \\
\text { Motta - UNISSUAM }\end{array}$ \\
\hline $\begin{array}{l}\text { Não trata de um } \\
\text { local específico }\end{array}$ & $\begin{array}{l}\text { AQUINO, M.; et al.A justiça e o racismo ambiental diante do rompimento da } \\
\text { barragem de Fundão (Mariana MG): A educação ambiental de base comunitária e os } \\
\text { movimentos sociais diante da problemática econômica e ambiental em torno da } \\
\text { mineração. In: EPEA - Encontro Pesquisa em Educação Ambiental, 9., 2017, Juiz de } \\
\text { Fora. Anais... Juiz de Fora: [s.n], v. 1, 2017. }\end{array}$ & $\begin{array}{l}\text { Universidade Federal } \\
\text { do Estado do Rio de } \\
\text { Janeiro e } \\
\text { Universidade Federal } \\
\text { de Juiz de Fora }\end{array}$ \\
\hline $\begin{array}{l}\text { Não trata de um } \\
\text { local específico }\end{array}$ & $\begin{array}{l}\text { ROSA, K. N. N. et al. A Responsabilidade da Empresa Samarco Frente aos Danos } \\
\text { Causados. In: Mostra de Iniciação Científica, 14., 2017, Bagé. Anais... Bagé: Urcamp, } \\
\text { 2017, p. 237-238. }\end{array}$ & $\begin{array}{l}\text { Centro Universitário } \\
\text { da Região da } \\
\text { Campanha }\end{array}$ \\
\hline $\begin{array}{l}\text { Não trata de um } \\
\text { local específico }\end{array}$ & $\begin{array}{l}\text { REZENDE, E. N.; MURTA, A. C. D.. A tragédia em Mariana no Brasil e o papel do } \\
\text { poder judiciário perante a degradação ambiental doméstica e internacional brasileira: o } \\
\text { conflito entre o Estado Brasileiro e as Jurisdições Federais e o Direito Internacional. } \\
\text { Revista Brasileira de Direito, Passo Fundo, v. 13, n. 2, p. 155-175, ago. } 2017 .\end{array}$ & $\begin{array}{l}\text { Escola Superior Dom } \\
\text { Helder Câmara e } \\
\text { Universidade } \\
\text { FUMEC. }\end{array}$ \\
\hline $\begin{array}{l}\text { Não trata de um } \\
\text { local específico }\end{array}$ & $\begin{array}{l}\text { CAMPOS, F. B. et al. A saga da Samarco: as revelações do relatórico contábil- } \\
\text { financeiro após o desastre de Mariana. Revista de Contabilidade da UFBA, } \\
\text { Salvador-Bahia. V. 11, N. 2, Pág.139-157, mai-ago } 2017\end{array}$ & $\begin{array}{l}\text { Universidade Federal } \\
\text { da Bahia }\end{array}$ \\
\hline $\begin{array}{l}\text { Não trata de um } \\
\text { local específico }\end{array}$ & $\begin{array}{l}\text { BARCELOS, T. S.; MOTA, L. F. A tragédia de Mariana/MG e a valoração econômica } \\
\text { e ambiental da área atingida: método TEEB. In: Simpósio de Produção Científica da } \\
\text { UNIFESSPA, 2., Marabá (PA), 2018. Anais... Marabá: UNIFESSPA, } 2018 .\end{array}$ & $\begin{array}{l}\text { Universidade Federal } \\
\text { do Sul e Sudeste do } \\
\text { Pará }\end{array}$ \\
\hline $\begin{array}{l}\text { Não trata de um } \\
\text { local específico }\end{array}$ & $\begin{array}{l}\text { SOUZA, R. M.; SANTOS, M. F. B. A tutela coletiva de direitos pelo Ministério } \\
\text { Público na acidentalidade da Samarco. Revista Científica Doctum: Direito, } \\
\text { Caratinga. v. 1, n. 2, dez } 2017 .\end{array}$ & Rede DOCTUM \\
\hline $\begin{array}{l}\text { Não trata de um } \\
\text { local específico }\end{array}$ & $\begin{array}{l}\text { DORNELAS, R. S. et al. Ações Civis Públicas e Termos de Ajustamento de Conduta } \\
\text { no caso do desastre ambiental da Samarco: considerações a partir do Observatório de } \\
\text { Ações Judiciais. In: MILANEZ, B.; LOSEKANN, C. Desastre no Vale do Rio Doce: } \\
\text { Antecedentes, impactos e ações sobre a destruição. Rio de Janeiro: Folio Digital, } \\
\text { 2016. cap. 9, p. 339-392. }\end{array}$ & $\begin{array}{l}\text { Organon - Núcleo de } \\
\text { Estudo, Pesquisa e } \\
\text { Extensão em } \\
\text { Mobilização Social, } \\
\text { da Universidade } \\
\text { Federal } \\
\text { do Espírito Santo. } \\
\text { Livro UFES }\end{array}$ \\
\hline $\begin{array}{l}\text { Não trata de um } \\
\text { local específico }\end{array}$ & $\begin{array}{l}\text { SOARES, A. F. S. et al. Alterações no licenciamento Ambiental de Barragens de rejeti } \\
\text { após o Desastre de Mariana-MG. In: Congresso Sulamericano de Resíduos Sólidos e } \\
\text { Sustentabilidade, 1., 2018, Gramado (RS). Anais... Gramado: IBEAS, } 2018 .\end{array}$ & $\begin{array}{l}\text { Centro Universitário } \\
\text { Metodista Izabela } \\
\text { Hendrix }\end{array}$ \\
\hline $\begin{array}{l}\text { Não trata de um } \\
\text { local específico }\end{array}$ & $\begin{array}{l}\text { LOPES, R. A. L. Caso do desastre socioambiental da Samarco: os desafios para a } \\
\text { responsabilização de empresas por violação de direitos humanos. In: MILANEZ, B.; } \\
\text { LOSEKANN, C. (Org.) . Desastre no Vale do Rio Doce: Antecedentes, impactos e } \\
\text { ações sobre a destruição. Rio de Janeiro: Folio Digital, 2016. cap. 10, p. 373-392. }\end{array}$ & $\begin{array}{l}\text { Justiça Global (Livro } \\
\text { UFES) }\end{array}$ \\
\hline $\begin{array}{l}\text { Não trata de um } \\
\text { local específico }\end{array}$ & $\begin{array}{l}\text { SOUZA, D. Q. Conflito de Competência Cível no Caso Samarco. 2016. } 34 \text { f. } \\
\text { Monografia (Graduação em Direito) - Escola de Direito de Brasília, Instituto } \\
\text { Brasiliense de Direito Público, - EDB, Brasília-DF, } 2016 .\end{array}$ & $\begin{array}{l}\text { INSTITUTO } \\
\text { BRASILIENSE DE } \\
\text { DIREITO PÚBLICO }\end{array}$ \\
\hline $\begin{array}{l}\text { Não trata de um } \\
\text { local específico }\end{array}$ & $\begin{array}{l}\text { REIS, A. L.; SILVA, F. A. R. AS CONTROVÉRSIAS NAS AULAS DE } \\
\text { BIOLOGIA A PARTIR DA LEITURA DE JORNAIS IMPRESSOS: O } \\
\text { DESASTRE AMBIENTAL DA SAMARCO. Ouro Preto: [s.n], } 2018 .\end{array}$ & $\begin{array}{l}\text { Universidade Federal } \\
\text { de Ouro Preto }\end{array}$ \\
\hline $\begin{array}{l}\text { Não trata de um } \\
\text { local específico }\end{array}$ & $\begin{array}{l}\text { ABREU, M. R.; SANTOS, P. S. Da sociedade do risco ao acidente socioambiental: } \\
\text { Violações a ordem constitucional e aos direitos humanos. Saberes da Amazônia, } \\
\text { Porto Velho, v. } 2 \text {, n. 5, p. 162-183, jul-dez } 2017 .\end{array}$ & $\begin{array}{l}\text { Observatório Goiano } \\
\text { de Direitos Humanos } \\
\text { (Faculdade de } \\
\text { Ciências Sociais- } \\
\text { FCS, da Universidade } \\
\text { Federal de Goiás) } \\
\end{array}$ \\
\hline $\begin{array}{l}\text { Não trata de um } \\
\text { local específico }\end{array}$ & $\begin{array}{l}\text { LOPES, M. G.; ZDANOWICZ, J. E. Cenários prospectivos: o caso do rompimento da } \\
\text { barragem em Mariana (MG). Revista do Desenvolvimento Regional - Faccat, } \\
\text { Taquara/RS, v. 14, n. 1, p. 193-213, jan./jun. } 2017\end{array}$ & $\begin{array}{l}\text { Faculdade Integrada } \\
\text { de Taquara/RS }\end{array}$ \\
\hline $\begin{array}{l}\text { Não trata de um } \\
\text { local específico }\end{array}$ & $\begin{array}{l}\text { SCALEI, I. L. G. Direito ambiental e a responsabilidade penal dos danos } \\
\text { ambientais: caso Samarco em Mariana-MG. } 2016.73 \text { f. Monografia (Graduação } \\
\text { em Direito) - Universidade Regional do Noroeste do Estado do Rio Grande do Sul, } \\
\text { ljuí (RS), 2016. }\end{array}$ & $\begin{array}{l}\text { Universidade } \\
\text { Regional do Noroeste } \\
\text { do Estado do Rio } \\
\text { Grande do Sul - } \\
\text { UNIJUÍ. }\end{array}$ \\
\hline $\begin{array}{l}\text { Não trata de um } \\
\text { local específico }\end{array}$ & $\begin{array}{l}\text { LEMOS, V. S. et al. Conservadorismo Contábil na Legitimação das Empresas de } \\
\text { Capital Aberto do setor de Minerio. In: USP Internacional Conference in Accounting, } \\
\text { 18., 2018, São Paulo. Anais... São Paulo: USP, } 2018 .\end{array}$ & $\begin{array}{l}\text { Universidade Federal } \\
\text { do Rio Grade }\end{array}$ \\
\hline $\begin{array}{l}\text { Não trata de um } \\
\text { local específico }\end{array}$ & $\begin{array}{l}\text { ZUCARELLI, M. C. Efeitos institucionais e políticos dos processos de mediação de } \\
\text { conflitos. In: MILANEZ, B.; LOSEKANN, C. (Org.). Desastre no Vale do Rio Doce: } \\
\text { Antecedentes, impactos e ações sobre a destruição. Rio de Janeiro: Folio Digital, }\end{array}$ & $\begin{array}{l}\text { GESTA - } \\
\text { Universidade Federal } \\
\text { de Minas Gerais. }\end{array}$ \\
\hline
\end{tabular}




\begin{tabular}{|c|c|c|}
\hline & 2016. cap. 8 , p. 311-338. & Livro (UFES) \\
\hline $\begin{array}{l}\text { Não trata de um } \\
\text { local específico }\end{array}$ & $\begin{array}{l}\text { MATOS, M. E. N. Gerenciamento de risco no licenciamento ambiental - o caso do } \\
\text { rompimento da barragem de Fundão. 2017, } 47 \text { f. Monografia (Bacharel em } \\
\text { Engenharia Ambiental), instituo de Ciências Agrárias, Universidade Federal de } \\
\text { Uberlândia, Uberlândia, } 2017 \text {. }\end{array}$ & $\begin{array}{l}\text { Universidade Federal } \\
\text { de Uberlândia }\end{array}$ \\
\hline $\begin{array}{l}\text { Não trata de um } \\
\text { local específico }\end{array}$ & $\begin{array}{l}\text { PINTO-COELHO, R. M. Existe governança das águas no Brasil? Estudo de caso: O } \\
\text { rompimento da Barragem de Fundão, Mariana (MG). Arquivos do Museu de } \\
\text { História Natural e Jardim Botânico - UFMG, Belo Horizonte, v. 24, n. 1/2, p. 16- } \\
\text { 43, } 2015 \text {. }\end{array}$ & $\begin{array}{l}\text { Universidade Federal } \\
\text { de Minas Gerais }\end{array}$ \\
\hline $\begin{array}{l}\text { Não trata de um } \\
\text { local específico }\end{array}$ & $\begin{array}{l}\text { HELLER, L.; MODE, C. M. Desastre da Samarco: Aproximações Iniciais. Cienc. } \\
\text { Cult., São Paulo, v. } 68 \text { n. 3, p. 22-24 jul./set., } 2016 .\end{array}$ & $\begin{array}{l}\text { Fiocruz, Instituto } \\
\text { René Rachou }\end{array}$ \\
\hline $\begin{array}{l}\text { Não trata de um } \\
\text { local específico }\end{array}$ & $\begin{array}{l}\text { WANDERLEY, L. J.; et al. Avaliação dos antecedentes econômicos, sociais e } \\
\text { institucionais do rompimento da barragem de rejeito da Samarco/ Vale/ BHP em } \\
\text { Mariana. In: MILANEZ, B.; LOSEKANN, C. (Org.). Desastre no Vale do Rio Doce: } \\
\text { Antecedentes, impactos e ações sobre a destruição. Rio de Janeiro: Folio Digital, } \\
\text { 2016. cap. 1, p. 39-90. }\end{array}$ & $\begin{array}{l}\text { PoeMAS - } \\
\text { Universidade Federal } \\
\text { do Rio de Janeiro, } \\
\text { Universidade } \\
\text { Estadual do Rio de } \\
\text { Janeiro, Instituto } \\
\text { Federal do Rio de } \\
\text { Janeiro. Livro UFES }\end{array}$ \\
\hline $\begin{array}{l}\text { Não trata de um } \\
\text { local específico }\end{array}$ & $\begin{array}{l}\text { SIMONATO, T. C.; et al. Desastres urbanos e a conjuntura econômica: O caso de } \\
\text { Mariana-MG. In: Encontro Nacional da Associação Nacional de Pós-Graduação e } \\
\text { Pesquisa em Planejamento Urbano e Regional, 17., 2017, São Paulo. Anais... São } \\
\text { Paulo: [s.n], 2017. }\end{array}$ & $\begin{array}{l}\text { CEDEPLAR - } \\
\text { Universidade Federal } \\
\text { de Minas Gerais }\end{array}$ \\
\hline $\begin{array}{l}\text { Não trata de um } \\
\text { local específico }\end{array}$ & $\begin{array}{l}\text { ELEUTÉRIO, M.; FERREIRA, R. A lama, o Ethos e uma mineradora entre as } \\
\text { montanhas: Análise Retórica do "Comunicado à sociedade', do diretor-presidente da } \\
\text { Samarco Mineração, após um dos maiores desastres ambientais brasileiros. Revista } \\
\text { Orbis Latina, Foz do Iguaçu, v.6, n.1, p. 56-62, Janeiro-Dezembro de } 2016 .\end{array}$ & $\begin{array}{l}\text { Universidade Federal } \\
\text { da Integração Latino- } \\
\text { Americana }\end{array}$ \\
\hline $\begin{array}{l}\text { Não trata de um } \\
\text { local específico }\end{array}$ & $\begin{array}{l}\text { CAMPOS, R. M. P.; SOBRAL, M. A. O acordado sai caro, e muito caro! Percepções } \\
\text { iniciais da Defensoria Pública acerca dos processos indenizatórios da Bacia do Rio } \\
\text { Doce. .In: LOSEKANN, C.; MAYORGA, C (Org). Desastre na Bacia do Rio Doce: } \\
\text { desafios para a universidade e para instituições estatais. Rio de Janeiro: Folio Digital } \\
\text { Letra e Imagem, 2018. cap. 6, p.147-171. }\end{array}$ & $\begin{array}{l}\text { Defensoria Pública - } \\
\text { ES. (Livro UFES) }\end{array}$ \\
\hline $\begin{array}{l}\text { Não trata de um } \\
\text { local específico }\end{array}$ & $\begin{array}{l}\text { CHAISE, M. J. C.; SPILKA, G. B. . A tragédia na barragem de Mariana sob a ótica } \\
\text { dos jornais portugueses. In: Congresso de Ciências da Comunicação na Região Sul, } \\
\text { 17., 2016, Curitiba. Anais ..., Curitiba: [s.n.], 2016. }\end{array}$ & $\begin{array}{l}\text { Universidade do } \\
\text { Porto, Porto, Portugal } \\
\text { Universidade de } \\
\text { Passo Fundo, RS, } \\
\text { Brasil }\end{array}$ \\
\hline $\begin{array}{l}\text { Não trata de um } \\
\text { local específico }\end{array}$ & $\begin{array}{l}\text { CAYRES, D. C. ; et al. Inovações institucionais no processo de produção de políticas } \\
\text { públicas: o caso do rompimento da barragem de Fundão em Mariana-MG. In: } \\
\text { Congresso Brasileiro de Sociologia, 18., 2017, Brasília. Anais ... São Paulo: } \\
\text { Sociedade Brasileira de Sociologia, 2017. }\end{array}$ & $\begin{array}{l}\text { Universidade Federal } \\
\text { do Espírito Santo }\end{array}$ \\
\hline $\begin{array}{l}\text { Não trata de um } \\
\text { local específico }\end{array}$ & $\begin{array}{l}\text { WANDERLEY, L. J. et al. Desastre da Samarco/Vale/BHP no Vale do Rio Doce: } \\
\text { aspectos econômicos, políticos e sócio ambientais. Cienc. Cult., São Paulo, v. } 68 \text {, n. } \\
\text { 3, p. } 30-35,2016 \text {. }\end{array}$ & $\begin{array}{l}\text { PoEMAS } \\
\text { (Universidade } \\
\text { Federal de Juiz de } \\
\text { Fora, Universidade } \\
\text { Federal do Rio de } \\
\text { Janeiro e } \\
\text { Universidade } \\
\text { Estadual do Rio de } \\
\text { Janeiro) } \\
\end{array}$ \\
\hline $\begin{array}{l}\text { Não trata de um } \\
\text { local específico }\end{array}$ & $\begin{array}{l}\text { ZHOURI, A.; et al. O desastre da Samarco e a política das afetações: classificações e } \\
\text { ações que produzem o sofrimento social. Ciência e Cultura, v. 68, p. 36-40, } 2016 .\end{array}$ & $\begin{array}{l}\text { Universidade Federal } \\
\text { de Minas Gerais }\end{array}$ \\
\hline $\begin{array}{l}\text { Não trata de um } \\
\text { local específico }\end{array}$ & $\begin{array}{l}\text { FERREIRA, S. R. B. F. Marcas da colonialidade do poder no conflito entre a } \\
\text { mineradora Samarco, os povos originários e as comunidades tradicionais do Rio Doce. } \\
\text { In: MILANEZ, B.; LOSEKANN, C. (Org.). Desastre no Vale do Rio Doce: } \\
\text { Antecedentes, impactos e ações sobre a destruição. Rio de Janeiro: Folio Digital, } \\
\text { 2016. cap. 7, p. 267-310. }\end{array}$ & $\begin{array}{l}\text { Observatório dos } \\
\text { Conflitos no Campo } \\
\text { (OCCA) - } \\
\text { Universidade Federal } \\
\text { do Espírito Santo }\end{array}$ \\
\hline $\begin{array}{l}\text { Não trata de um } \\
\text { local específico }\end{array}$ & $\begin{array}{l}\text { XAVIER, J. B.; VIEIRA, L. P. O. O trabalho e seus sentidos: a destruição da força } \\
\text { humana que trabalha. In: MILANEZ, B.; LOSEKANN, C. (Org.). Desastre no Vale } \\
\text { do Rio Doce: Antecedentes, impactos e ações sobre a destruição. Rio de Janeiro: Folio } \\
\text { Digital, 2016. cap. 5, p. 197-232. }\end{array}$ & $\begin{array}{l}\text { Coletivo Margarida } \\
\text { Alves de Assessoria } \\
\text { Popular - Livro UFES }\end{array}$ \\
\hline $\begin{array}{l}\text { Não trata de um } \\
\text { local específico }\end{array}$ & $\begin{array}{l}\text { FONTES, R. N.; LOPES, I. S. As representações da mídia sobre o rompimento da } \\
\text { barragem do Fundão em Mariana, Minas Gerais. Revista Espacios, [S.1.], v. 38, n. 34, } \\
2017 \text {. }\end{array}$ & $\begin{array}{l}\text { Universidade Federal } \\
\text { de Viçosa }\end{array}$ \\
\hline $\begin{array}{l}\text { Não trata de um } \\
\text { local específico }\end{array}$ & $\begin{array}{l}\text { LOPES, D. K. Contraimagens - Sobre os usos corporativos repressivos das imagens de } \\
\text { protesto. In: MILANEZ, B.; LOSEKANN, C. (Org.). Desastre no Vale do Rio Doce: } \\
\text { Antecedentes, impactos e ações sobre a destruição. Rio de Janeiro: Folio Digital, } \\
\text { 2016. cap. } 11, \text { p.393-400. }\end{array}$ & $\begin{array}{l}\text { Organon } \\
\text { (Universidade } \\
\text { Federal do Espírito } \\
\text { Santo). Livro UFES }\end{array}$ \\
\hline
\end{tabular}




\begin{tabular}{|c|c|c|}
\hline $\begin{array}{l}\text { Não trata de um } \\
\text { local específico }\end{array}$ & $\begin{array}{l}\text { PORTO, M. P. S. A tragédia da mineração e do desenvolvimento no Brasil: desafios } \\
\text { para a saúde coletiva. }\end{array}$ & Fiocruz \\
\hline $\begin{array}{l}\text { Não trata de um } \\
\text { local específico }\end{array}$ & $\begin{array}{l}\text { TEIXEIRA, H. M. S. V; RODRIGUES, S. B. OS VAZIOS INSTITUCIONAIS NA } \\
\text { MINERAÇÃO: UM ESTUDO DE CASO DE MARIANA. Revista Tecer, Belo } \\
\text { Horizonte, v. 9, n. 17, } 2016 .\end{array}$ & $\begin{array}{l}\text { Universidade } \\
\text { FUMEC e Faculdade } \\
\text { de Estudos } \\
\text { Administrativos de } \\
\text { Minas Gerais } \\
\end{array}$ \\
\hline $\begin{array}{l}\text { Não trata de um } \\
\text { local específico }\end{array}$ & $\begin{array}{l}\text { VIEIRA, D. R. Diálogos de um desastre: comunicação e discursos da Samarco Renova } \\
\text { em sua interlocução com os atingidos pela catástrofe socioambiental no Vale do Rio } \\
\text { Doce. In: Seminário de Ciências Sociais, 2., 2017, Vitória. Anais... Vitória: } \\
\text { Universidade Federal do Espírito Santo, 2017. }\end{array}$ & $\begin{array}{l}\text { Universidade Federal } \\
\text { do Espírito Santo }\end{array}$ \\
\hline $\begin{array}{l}\text { Não trata de um } \\
\text { local específico }\end{array}$ & $\begin{array}{l}\text { MULBHEIER, A. LEITURA DO DESASTRE DE MARIANA MG READING OF } \\
\text { THE DISASTER OF MARIANA MG. Seminário de Iniciação Científica, 25., 2017, } \\
\text { Ijuí. Anais... Ijuí: Unijuí, 2017. }\end{array}$ & \begin{tabular}{|l} 
UNIJUÍ \\
\end{tabular} \\
\hline $\begin{array}{l}\text { Não trata de um } \\
\text { local específico }\end{array}$ & $\begin{array}{l}\text { ACSELRAD, H. Mariana, novembro de 2015: A genealogia Política de um desastre. } \\
\text { In: ZHOURI, A. (Org). Mineração, Violências e Resistências: Um campo aberto à } \\
\text { produção de conhecimentos no Brasil. Marabá (Pará): iGuana, 2018. cap. 2, p. 65-110. }\end{array}$ & $\begin{array}{l}\text { Universidade Federal } \\
\text { do Rio de Janeiro - } \\
\text { Livro (ABA) }\end{array}$ \\
\hline $\begin{array}{l}\text { Não trata de um } \\
\text { local específico }\end{array}$ & $\begin{array}{l}\text { SILVA, C. M. R.; PEREIRA, J. V. Modelos matemáticos relacionados ao desastre do } \\
\text { Rio Doce. In: SemEAr - Semana de Estudos da Engenharia Ambiental, Rio Claro-SP. } \\
\text { Anais do XIII SemEAr, } 2016 .\end{array}$ & $\begin{array}{l}\text { Universidade } \\
\text { Estadual Paulista- } \\
\text { "Júlio de Mesquita } \\
\text { Filho" }\end{array}$ \\
\hline $\begin{array}{l}\text { Não trata de um } \\
\text { local específico }\end{array}$ & $\begin{array}{l}\text { BUENO, W. C. GESTÃO DA COMUNICAÇÃO EM DESASTRES AMBIENTAIS } \\
\text { conflitos de interesse, de práticas e de discursos. Revista Observatório, Palmas, v. } 4 \text {, } \\
\text { n. } 2 \text {, p. 539-569, abr-jun. } 2018\end{array}$ & $\begin{array}{l}\text { Universidade } \\
\text { Metodista de São } \\
\text { Paulo }\end{array}$ \\
\hline $\begin{array}{l}\text { Não trata de um } \\
\text { local específico }\end{array}$ & $\begin{array}{l}\text { ANDRADE, F. L.; SILVA, L. G. B. Precedentes Judiciais, Responsabilidade Civil } \\
\text { Ambiental e a tragédia de Mariana. REPATS, Brasília, v. 4, n. 2, p.89-105, Jul-Dez, } \\
2017\end{array}$ & Dom Helder Câmara \\
\hline $\begin{array}{l}\text { Não trata de um } \\
\text { local específico }\end{array}$ & $\begin{array}{l}\text { BITTENCOURT, C. Política da Ecologia e ecologia política. As relações } \\
\text { institucionais da Samarco e do Estado no desastre em Mariana. In: ALMONADA, H.; } \\
\text { PEREZ, C. T.; MARTIN, F. Ecología Política Latinoamericana. Buenos Aires: } \\
\text { CLACSO, 2017. p. 303-319. }\end{array}$ & $\begin{array}{l}\text { Universidade Federal } \\
\text { Rural do Rio De } \\
\text { Janeiro }\end{array}$ \\
\hline $\begin{array}{l}\text { Não trata de um } \\
\text { local específico }\end{array}$ & $\begin{array}{l}\text { FARIA, M.; BOTELHO, M. O Rompimento da Barragem de Fundão em Mariana, } \\
\text { Minas Gerais, Brasil: a Incubação de um Acidente Organizacional. .Revista } \\
\text { Portuguesa de Saúde Ocupacional, [S.1.], v. 5, p. } 73-85,2018 .\end{array}$ & $\begin{array}{l}\text { Universidade } \\
\text { FUMEC e PUC- } \\
\text { Minas }\end{array}$ \\
\hline $\begin{array}{l}\text { Não trata de um } \\
\text { local específico }\end{array}$ & $\begin{array}{l}\text { PINTO. A. S. C. GEST ÃO DE CRISE E COMUNICAÇÃO: O CASO SAMARCO. } \\
\text { 2016. } 42 \text { f. Monografia (Graduação em Publicidade e Propaganda), Faculdade De } \\
\text { Tecnologia E Ciências Sociais Aplicadas, Centro Universitário de Brasília, Brasília. } \\
2016 .\end{array}$ & $\begin{array}{l}\text { Centro Universitário } \\
\text { de Brasília }\end{array}$ \\
\hline $\begin{array}{l}\text { Não trata de um } \\
\text { local específico }\end{array}$ & $\begin{array}{l}\text { CENI, J. C. O PROCESSO DE SENSEGIVING NAS NARRATIVAS DA } \\
\text { SAMARCO: A prática de storytelling referente ao rompimento na barragem de } \\
\text { Fundão em Mariana. 2018. } 169 \text { f. Dissertação (Mestrado em Administração), Setor de } \\
\text { Ciências Sociais Aplicadas, Universidade Federal do Paraná, Curitiba, 2018. }\end{array}$ & $\begin{array}{l}\text { Universidade Federal } \\
\text { do Paraná }\end{array}$ \\
\hline $\begin{array}{l}\text { Não trata de um } \\
\text { local específico }\end{array}$ & $\begin{array}{l}\text { BRAUNA, M. S. O discurso organizacional em crises - uma análise da Samarco no } \\
\text { momento de Pré Crise, Crise e Pós Crise. In: Interprogamas, 3., 2017, Brasília. } \\
\text { Anais... Brasília: [s.n], } 2017 .\end{array}$ & $\begin{array}{l}\text { Universidade } \\
\text { Católica de Brasília }\end{array}$ \\
\hline $\begin{array}{l}\text { Não trata de um } \\
\text { local específico }\end{array}$ & $\begin{array}{l}\text { BRASIL, L. M. et al. O QUE A LAMA NOS DEIXOU: REFLEXÕES SOBRE A } \\
\text { TRAGÉDIA DE MARIANA, A MÍDIA E A MINERAÇÃO NO BRASIL. } \\
\text { Observatoire des amériques montréal., [S.1.], v. 7, n. 3, } 2017\end{array}$ & $\begin{array}{l}\text { Universidade de } \\
\text { Brasília }\end{array}$ \\
\hline $\begin{array}{l}\text { Não trata de um } \\
\text { local específico }\end{array}$ & $\begin{array}{l}\text { BARROS, G. L. V. Regular, reparar e resistir : um estudo sobre a ação (e omissão) } \\
\text { dos agentes envolvidos no desastre tecnológico no Vale do Rio Doce. 2018. 93f. } \\
\text { Monografia (Bacharel em Administração), Escola de Governo, Fundação João } \\
\text { Pinheiro, Belo Horizonte, 2018. }\end{array}$ & $\begin{array}{l}\text { Fundação João } \\
\text { Pinheiro }\end{array}$ \\
\hline $\begin{array}{l}\text { Não trata de um } \\
\text { local específico }\end{array}$ & $\begin{array}{l}\text { ARAUJO, N. M. O rompimento da barragem de Fundão em Mariana (MG): do } \\
\text { acontecimento histórico ao estudo discursivo das charges. 2016. 105f. Dissertação } \\
\text { (Mestrado em Letras), Universidade Católica de Pelotas, Pelotas, 2016. }\end{array}$ & $\begin{array}{l}\text { Universidade } \\
\text { Católica de Pelotas }\end{array}$ \\
\hline $\begin{array}{l}\text { Não trata de um } \\
\text { local específico }\end{array}$ & $\begin{array}{l}\text { FILHO, H. N. et al. RESPONSABILIDADE CIVIL POR DANO AMBIENTAL } \\
\text { DECORRENTE DO ROMPIMENTO DAS BARRAGENS DO FUNDÃO, EM } \\
\text { MARIANA, MINAS GERAIS. Multitemas, Campo Grande, v. 25, n. 50, p. 281-301, } \\
2016 .\end{array}$ & $\begin{array}{l}\text { Centro Universitário } \\
\text { Augusto } \\
\text { Motta. - UNISSUAM }\end{array}$ \\
\hline $\begin{array}{l}\text { Não trata de um } \\
\text { local específico }\end{array}$ & $\begin{array}{l}\text { JUNIOR, N. S. T ; et al. Os efeitos econômicos do rompimento de barragem de } \\
\text { resíduos: divulgações nas demonstrações contábeis comparativamente à grande mídia. } \\
\text { In: Encontro Internacional sobre Gestão Empresarial e Meio Ambiente, 18., 2016, São } \\
\text { Paulo. Anais... São Paulo: FEA USP, 2017. }\end{array}$ & $\begin{array}{l}\text { Universidade de São } \\
\text { Paulo }\end{array}$ \\
\hline $\begin{array}{l}\text { Não trata de um } \\
\text { local específico }\end{array}$ & $\begin{array}{l}\text { BRITES, F. et al. O Telejornalismo e a Cobertura de Desastres Ambientais: uma } \\
\text { Análise do Caso Samarco. In: Congresso Brasileiro de Ciências da Comunicação, 39., } \\
\text { 2016, São Paulo. Anais... São Paulo: INTERCOM, 2016, p. 1-15. }\end{array}$ & $\begin{array}{l}\text { Universidade Federal } \\
\text { do Rio Grande do Sul }\end{array}$ \\
\hline $\begin{array}{l}\text { Não trata de um } \\
\text { local específico }\end{array}$ & $\begin{array}{l}\text { CARVALHO, L. M. A. A INTERVENÇÃO ESTATAL VIA EXAÇÕES (TRFM E } \\
\text { CFEM) SOB A PERSPECTIVA DA PROTEÇÃO DO MEIO AMBIENTE NA }\end{array}$ & $\begin{array}{l}\text { Universidade } \\
\text { FUMEC }\end{array}$ \\
\hline
\end{tabular}




\begin{tabular}{|c|c|c|}
\hline & $\begin{array}{l}\text { ATIVIDADE MINERÁRIA E O "CASO SAMARCO". 2017. } 107 \text { f. Dissertação } \\
\text { (Mestrado em Direito), Faculdade de Ciências Humanas, Sociais e da Saúde, } \\
\text { Universidade FUMEC, Belo Horizonte, } 2017 .\end{array}$ & \\
\hline $\begin{array}{l}\text { Não trata de um } \\
\text { local específico }\end{array}$ & $\begin{array}{l}\text { CRUZ, F. V. S. DESEMPENHO DE SEMENTES E PLÂNTULAS DE } \\
\text { ESPÉCIES ARBÓREAS NO REJEITO ORIUNDO DO ROMPIMENTO DA } \\
\text { BARRAGEM DE FUNDÃO (MARIANA, MG). 2018. } 37 \text { f. Dissertação (Mestrado } \\
\text { em Biologia Vegetal), Instituto de Ciências Biológicas, Universidade Federal de } \\
\text { Minas Gerais, 2018. }\end{array}$ & $\begin{array}{l}\text { Universidade Federal } \\
\text { de Minas Gerais }\end{array}$ \\
\hline $\begin{array}{l}\text { Não trata de um } \\
\text { local específico }\end{array}$ & $\begin{array}{l}\text { CORRÊA, K. A RESPONSABILIDADE CIVIL AMBIENTAL DA SAMARCO } \\
\text { DIANTE DO ROMPIMENTO DA BARRAGEM DE REJEITOS EM } \\
\text { MARIANA/MG. FesPR Publica, [S.1.], v. 2, n. 3, } 2018 .\end{array}$ & $\begin{array}{l}\text { Faculdade de } \\
\text { Educação Superior do } \\
\text { Paraná }\end{array}$ \\
\hline $\begin{array}{l}\text { Não trata de um } \\
\text { local específico }\end{array}$ & $\begin{array}{l}\text { CAMPOS, R. B. F. et al. Risco, desastre e educação ambiental: a terceira margem do } \\
\text { rio Doce. PERCURSOS, FLORIANÓPOLIS, v. 18, p. 66-94, } 2017 .\end{array}$ & $\begin{array}{l}\text { Universidade Vale do } \\
\text { Rio Doce }\end{array}$ \\
\hline $\begin{array}{l}\text { Não trata de um } \\
\text { local específico }\end{array}$ & $\begin{array}{l}\text { FEITOSA, S. Al.; ALVES, G. P. A. Os enquadramentos de uma cobertura: Tragédia } \\
\text { de Mariana. Vozes e Diálogo, Itajaí. v. 16, n. 1, } 2017\end{array}$ & UNIPAMPA \\
\hline $\begin{array}{l}\text { Não trata de um } \\
\text { local específico }\end{array}$ & $\begin{array}{l}\text { STEVES, N. D.; GUIDINI, P. Samarco e a Responsabilidade Socioambiental como } \\
\text { Ferramenta de Marketing. In: Encontro Toledo de Iniciação Científica Prof. Dr. } \\
\text { Sebastião Jorge Chammé, 12., 2016, Presidente Prudente. Anais... Presidente } \\
\text { Prudente: Etic - Encontro de Iniciação Científica, v. 12, } 2016 .\end{array}$ & $\begin{array}{l}\text { Centro Universitário } \\
\text { Antônio Eufrásio de } \\
\text { Toledo }\end{array}$ \\
\hline $\begin{array}{l}\text { Não trata de um } \\
\text { local específico }\end{array}$ & $\begin{array}{l}\text { GOULART, M. F.; KEGLER, J. Q. S.; TEIXEIRA, I. S. Samarco Mineradora S.A. e o } \\
\text { desastre em Mariana: (I)rresponsabilidade Social e falhas comunicacionais. In: } \\
\text { Congresso Brasileiro de Ciências da Comunicação, 40, 2017, Curitiba. Anais... } \\
\text { Curitiba: INTERCOM, } 2017 .\end{array}$ & $\begin{array}{l}\text { Universidade Federal } \\
\text { de Santa Maria }\end{array}$ \\
\hline $\begin{array}{l}\text { Não trata de um } \\
\text { local específico }\end{array}$ & $\begin{array}{l}\text { CÂMARA, M. T. P. Tocando na Cicatriz: Pontos de Vista e Enquadramento Sobre o } \\
\text { Rompimento da Barragem de Bento Rodrigues. In: Encontro Nacional de } \\
\text { Pesquisadores em Jornalismo, 15., 2017, São Paulo. Anais... São Paulo: Associação } \\
\text { Brasileira de Pesquisadores em Jornalismo, } 2017 .\end{array}$ & $\begin{array}{l}\text { Centro Federal de } \\
\text { Educação } \\
\text { Tecnológica de Minas } \\
\text { Gerais, Belo } \\
\text { Horizonte }\end{array}$ \\
\hline $\begin{array}{l}\text { Não trata de um } \\
\text { local específico }\end{array}$ & $\begin{array}{l}\text { LOPES, M.; BIAZATTI, B. O. Extrativism in the Global Market and Human Rights: } \\
\text { The Tragedy of the Mudslide in Mariana (2015). BRASILIANA- Journal for } \\
\text { Brazilian Studies, [S.1.], v. 5, n. 2, p. 5-28, 2017. }\end{array}$ & $\begin{array}{l}\text { Universidade Federal } \\
\text { de Minas Gerais }\end{array}$ \\
\hline $\begin{array}{l}\text { Não trata de um } \\
\text { local específico }\end{array}$ & $\begin{array}{l}\text { SAIZAKI, W. H.; VIEIRA, A. G.Tragédia em Mariana: uma análise da gestão de crise } \\
\text { da Samarco. In: Congresso de Ciências da Comunicação na Região Sudeste, 21., 2016, } \\
\text { Salto. Anais..., Salto: [s.n], } 2016 .\end{array}$ & $\begin{array}{l}\text { Universidade } \\
\text { Tecnológica Federal } \\
\text { do Paraná }\end{array}$ \\
\hline $\begin{array}{l}\text { Não trata de um } \\
\text { local específico }\end{array}$ & $\begin{array}{l}\text { CARVALHO, A. G. S. A sociedade do espetáculo e a Samarco: Uma Análise } \\
\text { Crítica Para Além da Metáfora. 2018. } 49 \text { f. Monografia (Bacharel em Administração). } \\
\text { Instituto de Ciências Sociais Aplicadas, Universidade Federal de Ouro Preto, Mariana, } \\
2018 .\end{array}$ & $\begin{array}{l}\text { Universidade Federal } \\
\text { de Ouro Preto }\end{array}$ \\
\hline $\begin{array}{l}\text { não trata de um } \\
\text { local específico }\end{array}$ & $\begin{array}{l}\text { COSTA, T. C. C. et al. Estabelecimento de Espécies Arbóreo-Arbustivas no } \\
\text { Rejeito de Minério de Ferro da Barragem do Fundão em Mariana-MG, Tratado } \\
\text { com Calcário, Fertilizantes e Microrganismos. Sete Lagoas: EMBRAPA Milho e } \\
\text { Sorgo, 2018. } 43 \text { p. (Boletim de Pesquisa e Desenvolvimento, n. 170) }\end{array}$ & $\begin{array}{l}\text { Embrapa Milho e } \\
\text { Sorgo }\end{array}$ \\
\hline $\begin{array}{l}\text { Não trata de um } \\
\text { local específico }\end{array}$ & $\begin{array}{l}\text { ENES, E. N. S. ; et al. Relações com o saber e o ambiente: olhares de estudantes sobre } \\
\text { o Rio Doce. IJET-PDVL, Recife, v. 1, n. 3, p. 61-77, set-dez } 2018 \text {. }\end{array}$ & $\begin{array}{l}\text { Universidade Vale do } \\
\text { Rio Doce }\end{array}$ \\
\hline $\begin{array}{l}\text { não trata de um } \\
\text { local específico }\end{array}$ & $\begin{array}{l}\text { ALEIXO, L. S. P. De Mariana à Mariana, perspectivas de uma Defensora Pública do } \\
\text { Espírito Santo sobre o maior crime socioambiental do Brasil. Foz, São Mateus, v. 1, n. } \\
\text { 2, p. 28-35, } 2018 \text {. }\end{array}$ & $\begin{array}{l}\text { Faculdade Milton } \\
\text { Campos }\end{array}$ \\
\hline $\begin{array}{l}\text { Não trata de um } \\
\text { local específico }\end{array}$ & $\begin{array}{l}\text { ANAZAWA, T. M. et al . O risco construído: reflexões sobre o desastre ocorrido em } \\
\text { Mariana, estado de Minas Gerais, em 2015, a partir da perspectiva da relação entre } \\
\text { população e ambiente. In: VII Congresso da Associação Latino-Americana de } \\
\text { População, 7. e Encontro Nacional de Estudos Populacionais, 20., 2016, Foz do } \\
\text { Iguaçu. Anais..., Foz do Iguaçu: [s.n], 2016. }\end{array}$ & $\begin{array}{l}\text { Universidade } \\
\text { Estadual de Campinas }\end{array}$ \\
\hline $\begin{array}{l}\text { Não trata de um } \\
\text { local específico }\end{array}$ & $\begin{array}{l}\text { SOUZA, L. R.; PAAZ, C. Democracia deliberativa e a consideração dos deslocados } \\
\text { ambientais: uma análise a partir do rompimento da Barragem de Fundão em } \\
\text { Mariana/MG. Direito e Desenvolvimento, João Pessoa, v. } 9 \text {, n. 2, p. } 249-269 \text {, ago/dez } \\
2018 \text {. }\end{array}$ & $\begin{array}{l}\text { Universidade de } \\
\text { Caxias do Sul }\end{array}$ \\
\hline $\begin{array}{l}\text { Não trata de um } \\
\text { local específico }\end{array}$ & $\begin{array}{l}\text { ROZIN, M. A tradução como direcionamento - o rompimento da barragem da } \\
\text { Samarco pelo olhar da mídia brasileira. 2018. } 136 \text { p. Dissertação (Mestrado em } \\
\text { Administração). Setor de Ciências Sociais Aplicadas, Universidade Federal do Paraná, } \\
2018 \text {. }\end{array}$ & $\begin{array}{l}\text { Universidade Federal } \\
\text { do Paraná }\end{array}$ \\
\hline $\begin{array}{l}\text { Não trata de um } \\
\text { local específico }\end{array}$ & $\begin{array}{l}\text { OLIVEIRA, R. L. S. A vida e a lama: Três Cinematografias seduzidas pela memória. } \\
\text { In: Congresso de Ciências da Comunicação na Região Nordeste, 2018, Juazeiro. } \\
\text { Anais... Juazeiro: Intercom, } 2018 .\end{array}$ & $\begin{array}{l}\text { Universidade } \\
\text { Estadual do Sudoeste } \\
\text { da Bahia }\end{array}$ \\
\hline $\begin{array}{l}\text { Não trata de um } \\
\text { local específico }\end{array}$ & $\begin{array}{l}\text { CARRATO, A.; et al. O crime ambiental de Mariana: omissão e conivência da mídia } \\
\text { brasileira. SCRIPTA, Belo Horizonte, v. 22, n. 45, p. 151-162, 2o quadrimestre de } \\
2018\end{array}$ & $\begin{array}{l}\text { Universidade Federal } \\
\text { de Minas Gerais }\end{array}$ \\
\hline
\end{tabular}




\begin{tabular}{|c|c|c|}
\hline $\begin{array}{l}\text { Não trata de um } \\
\text { local específico }\end{array}$ & $\begin{array}{l}\text { ROLAND, M. C. et al. Negociação em contextos de violações de Direitos Humanos } \\
\text { por empresas: Uma breve análise dos mecanismos de solução negociada à luz do caso } \\
\text { do rompimento da barragem de Fundão. Versos, [S.1.], v. 2, n. 1, p. 3-25, } 2018 \text {. }\end{array}$ & $\begin{array}{l}\text { Homa }- \text { Centro de } \\
\text { Direitos Humanos e } \\
\text { Empresas, } \\
\text { Universidade Federal } \\
\text { de Juiz de Fora }\end{array}$ \\
\hline $\begin{array}{l}\text { Não trata de um } \\
\text { local específico }\end{array}$ & $\begin{array}{l}\text { PONTES, N. A. E. Questão Ambiental e crimes industriais sob a lógica capitalista. } \\
\text { 2017. } 159 \text { f. Dissertação (Mestrado em Serviço Social), Faculdade de Serviço Social, } \\
\text { Universidade Federal de Juiz de Fora, Juiz de Fora, } 2017 .\end{array}$ & $\begin{array}{l}\text { Universidade Federal } \\
\text { de Juiz de Fora }\end{array}$ \\
\hline $\begin{array}{l}\text { Não trata de um } \\
\text { local específico }\end{array}$ & $\begin{array}{l}\text { CARVALHO, N. F.; ALMEIDA, J. Sentidos de justiça e mediação de conflito } \\
\text { ambiental: o caso do rompimento da Barragem de Fundão. Braz. Ap. Sci. Rev., } \\
\text { Curitiba, v. 2, n. 3, p. 982-998, jul./set. } 2018 \text {. }\end{array}$ & $\begin{array}{l}\text { Universidade Federal } \\
\text { do Rio Grande do Sul }\end{array}$ \\
\hline $\begin{array}{l}\text { Não trata de um } \\
\text { local específico }\end{array}$ & $\begin{array}{l}\text { SILVA, L. C. R. S. Barragens de rejeitos na indústria mineral brasileira. } 2017 . \\
\text { 52f. Monografia (Bacharel em Engenharia Química), Faculdade de Engenharia } \\
\text { Química, Universidade Federal de Uberlândia, Uberlândia, } 2017 .\end{array}$ & $\begin{array}{l}\text { Universidade Federal } \\
\text { de Uberlândia }\end{array}$ \\
\hline $\begin{array}{l}\text { Não trata de um } \\
\text { local específico }\end{array}$ & $\begin{array}{l}\text { ARAUJO, F. S. M. et al. Avaliação das Reações do mercado de capitais no Brasil e na } \\
\text { Austrália após o acidente ambiental da mineradora Samarco. Revista Catarinense da } \\
\text { Ciências Contábil, Florianópolis, v. } 17, \text { n. } 52 \text {, p. } 7-22 \text {, set./dez. } 2018\end{array}$ & $\begin{array}{l}\text { Universidade Federal } \\
\text { do Ceará }\end{array}$ \\
\hline $\begin{array}{l}\text { Não trata de um } \\
\text { local específico }\end{array}$ & $\begin{array}{l}\text { ZAMBRANO, R. J. M. et al. Comportamento e projeto de barragem de rejeitos } \\
\text { construída para Montante. 2018. } 105 \text { f. Monografia (Bacharel em Engenharia Civil), } \\
\text { Universidade de São Paulo, 2018. }\end{array}$ & $\begin{array}{l}\text { Universidade de São } \\
\text { Paulo }\end{array}$ \\
\hline $\begin{array}{l}\text { Não trata de um } \\
\text { local específico }\end{array}$ & $\begin{array}{l}\text { VIEIRA, D. R. Diálogos de um desastre: discursos e lógicas de poder no processo de } \\
\text { reparação dos danos gerados pelo rompimento da barragem da Samarco. In: Seminário } \\
\text { de Ciências Sociais- PGCS- Universidade Federal do Espírito Santo, 3., 2018, Vitória. } \\
\text { Anais... Vitória: Universidade Federal do Espírito Santo, 2018. }\end{array}$ & $\begin{array}{l}\text { Universidade Federal } \\
\text { do Espírito Santo }\end{array}$ \\
\hline $\begin{array}{l}\text { Não trata de um } \\
\text { local específico }\end{array}$ & $\begin{array}{l}\text { LIMA, G. S; MOSCHEM, M. Orientações Ideológicas das informações científcas: o } \\
\text { caso da abordagem do rompimento da Barragem de Fundão presente na revista Veja. } \\
\text { Journal of Science Communication, [S.l.], v. 1, n. 1, } 2018 \text {. }\end{array}$ & $\begin{array}{l}\text { Universidade Federal } \\
\text { de Ouro Preto }\end{array}$ \\
\hline $\begin{array}{l}\text { Não trata de um } \\
\text { local específico }\end{array}$ & $\begin{array}{l}\text { SOUZA, R. M.; FARIA, E. F. Análise da Responsabilidade Civil do Estado por } \\
\text { omissão: estudo de caso sobre a acidentalidade provocada pelo rompimento da } \\
\text { Barragem em Mariana/MG. In: BASSO, A. P. et al. Direito administrativo } \\
\text { e gestão pública e direito urbanístico, cidade e alteridade. Zaragoza: Prensas de La } \\
\text { Universidad de Zaragoza, 2018. p. 93-132. }\end{array}$ & $\begin{array}{l}\text { Rede DOCTUM e } \\
\text { PUC-Minas }\end{array}$ \\
\hline $\begin{array}{l}\text { Não trata de um } \\
\text { local específico }\end{array}$ & $\begin{array}{l}\text { LIMA, F. J. G.; SILVA, F. G. É possível pensar um socioambientalismo em } \\
\text { Habermas? Apontamentos a partir da ética discursiva e do direito. In: CALGARO, C.; } \\
\text { SANGALLI, I. J. (org.). Ética, direitos humanos e socioambientalismo. Caxias do } \\
\text { Sul: EDUCS, 2018. cap. } 6 \text {. }\end{array}$ & $\begin{array}{l}\text { Universidade Federal } \\
\text { do Piauí e UF do Rio } \\
\text { Grande do Sul }\end{array}$ \\
\hline $\begin{array}{l}\text { Não trata de um } \\
\text { local específico }\end{array}$ & $\begin{array}{l}\text { QUINTELA, R. S.; FAN, F. M. Estudo de aplicação preliminar do modelo SIAQUA- } \\
\text { IPH para dispersão longitudinal de sedimentos em rios. In: Simpósio Brasileiro de } \\
\text { Recursos Hídricos, 22., 2017, Florianópolis. Anais... Florianópolis: ABRH, } 2017 .\end{array}$ & $\begin{array}{l}\text { Instituto de Pesquisas } \\
\text { Hidráulicas - } \\
\text { Universidade Federal } \\
\text { do Rio Grande do Sul }\end{array}$ \\
\hline $\begin{array}{l}\text { Não trata de um } \\
\text { local específico }\end{array}$ & $\begin{array}{l}\text { LIMA, M.; et al. Modelagem e Simulação da Dispersãoo de Poluição no Desastre de } \\
\text { Mariana Utilizando o Método de Diferenças Finitas. Proceeding Series of the } \\
\text { Brazilian Society of Computacional and Applied Mathematics, [S.1.], v. 6, n. 2, } \\
2018 \text {. }\end{array}$ & \begin{tabular}{|l} 
Universidade \\
Estadual de Campinas
\end{tabular} \\
\hline $\begin{array}{l}\text { Não trata de um } \\
\text { local específico }\end{array}$ & $\begin{array}{l}\text { VARELA, L. G. DA SAMARCO AO JORNAL NACIONAL: RELAÇÕES ENTRE } \\
\text { A COMUNICAÇÃO ORGANIZACIONAL E O TELEJORNALISMO NO } \\
\text { DESASTRE EM MARIANA - MG. 2018. 334p. Dissetação (Mestrado em } \\
\text { Jornalismo), Centro de Comunicação e Expressão, Universidade Federal de Santa } \\
\text { Catarina, Florianópolis, } 2018 .\end{array}$ & $\begin{array}{l}\text { Universidade Federal } \\
\text { de Santa Catarina }\end{array}$ \\
\hline $\begin{array}{l}\text { Não trata de um } \\
\text { local específico }\end{array}$ & $\begin{array}{l}\text { OLIVEIRA, M. M. Passivos ambientais na empresa mineradora Samarco: Estudo } \\
\text { dos impactos nas demonstrações contábeis. 2018. 40p. Monografia (Bacharelado em } \\
\text { Ciências Contábeis), Centro Sócio-Econômico, Universidade Federal de Santa } \\
\text { Catarina, Florianópolis, } 2018 \text {. }\end{array}$ & $\begin{array}{l}\text { Universidade Federal } \\
\text { de Santa Catarina }\end{array}$ \\
\hline $\begin{array}{l}\text { Não trata de um } \\
\text { local específico }\end{array}$ & $\begin{array}{l}\text { GAMA, E. M; CORDEIRO, R. A. C.; SEERIG, T. Metakflex - o cimento de argilas: } \\
\text { Novo produto e nova receita para a eliminação de barragens de estéreis na mineração. } \\
\text { Arquivos do Museu de História Natural e Jardim Botânico - UFMG, Belo } \\
\text { Horizonte, v. } 24, \text { n. } 1 / 2 \text {, p. } 183-208,2015 \text {. }\end{array}$ & $\begin{array}{l}\text { Universidade Federal } \\
\text { de Minas Gerais }\end{array}$ \\
\hline $\begin{array}{l}\text { Não trata de um } \\
\text { local específico }\end{array}$ & $\begin{array}{l}\text { MEIRELES, L. V. Projeto de uma rede de internet das coisas para } \\
\text { monitoramento e alerta de emergência em áreas de risco. 2018. } 134 \text { f. Dissertação } \\
\text { (Mestrado em Instrumentação, Controle e Automação de Processos de Mineração) - } \\
\text { Escola de Minas, Universidade Federal de Ouro Preto, Ouro Preto, } 2018 .\end{array}$ & $\begin{array}{l}\text { Universidade Federal } \\
\text { de Ouro Preto }\end{array}$ \\
\hline $\begin{array}{l}\text { Não trata de um } \\
\text { local específico }\end{array}$ & $\begin{array}{l}\text { DOS SANTOS, R. S. P.; MILANEZ, B. A construção do desastre e a 'Privatização' } \\
\text { daregulação mineral: Reflexões a partir do caso do Vale do Rio Doce.In: ZHOURI, A. } \\
\text { (Org). Mineração, Violências e Resistências: Um campo aberto à produção de } \\
\text { conhecimentos no Brasil. Marabá (Pará): iGuana, 2018. cap. 3, p. 111-154. }\end{array}$ & $\begin{array}{l}\text { PoEMAS - } \\
\text { Universidade Federal } \\
\text { do Rio de Janeiro- } \\
\text { Universidade Federal } \\
\text { de Juiz de Fora. Livro } \\
\text { (ABA) }\end{array}$ \\
\hline Não trata de um & SIQUEIRA, M. R.; MACIEL, L. R. M.A formulação de Pc & Universidade Federal \\
\hline
\end{tabular}




\begin{tabular}{|c|c|c|}
\hline local específico & $\begin{array}{l}\text { Emergenciais frente a grandes desastres ambientais: o caso do rompimento da } \\
\text { barragem de rejeito da Samarco. In: Encontro Internacional de Ciências Sociais e } \\
\text { Barragens, 4., 2016, Chapecó. Anais... Chapecó: UFFS, } 2016 .\end{array}$ & $\begin{array}{l}\text { de Minas Gerais e } \\
\text { Izabela Hendrix }\end{array}$ \\
\hline $\begin{array}{l}\text { Não trata de um } \\
\text { local específico }\end{array}$ & $\begin{array}{l}\text { CÉSAR. P.S.M; CARNEIRO, R. A Gestão ambiental em Minas Gerais: Uma Análise } \\
\text { do Sistema de Gestão Ambiental e do Rompimento de Barragem de Rejeitos em } \\
\text { Mariana. Revista Livre de Sustentabilidade e Empreendedorismo, v 2, n. 2,p. 192- } \\
\text { 217, abr./jun. 2016. }\end{array}$ & $\begin{array}{l}\text { Fundação João } \\
\text { Pinheiro }\end{array}$ \\
\hline $\begin{array}{l}\text { Não trata de um } \\
\text { local específico }\end{array}$ & $\begin{array}{l}\text { SILVA, R. G. M. et al. A DESCONSIDERAÇÃO DA PESSOA JURÍDICA EM } \\
\text { CASOS DE DESASTRES AMBIENTAIS: ESTUDO DE CASO DO ROMPIMENTO } \\
\text { DA BARRAGEM EM MARIANA/MG. REVISTA FIDES, [S.l.], v. 8, p. 7-17, } 2017 .\end{array}$ & $\begin{array}{l}\text { Universidade Federal } \\
\text { do Rio Grande do } \\
\text { Norte }\end{array}$ \\
\hline $\begin{array}{l}\text { Não trata de um } \\
\text { local específico }\end{array}$ & $\begin{array}{l}\text { SANTOS, E. D. ; et al. É sempre bom olhar para todos os lados-: semiótica da } \\
\text { imagem na campanha empresarial da Samarco. SESSOOES DO IMAGINÁRIO } \\
\text { (ONLINE), [S.1.], v. } 22 \text {, p. } 110-119,2017 \text {. }\end{array}$ & Universidade Feevale \\
\hline $\begin{array}{l}\text { Não trata de um } \\
\text { local específico }\end{array}$ & $\begin{array}{l}\text { CRUZ, N. R.; NASCIMENTO, T. G. A análise da interação na fanpage da Samarco } \\
\text { durante a tragédia de Mariana. In: Congresso de Ciências da Comunicação na Região } \\
\text { Norte, 16, 2017, Manaus. Anais..., Manaus: [s.n], } 2017 .\end{array}$ & $\begin{array}{l}\text { Universidade Federal } \\
\text { do Amazonas }\end{array}$ \\
\hline $\begin{array}{l}\text { Toda a Bacia do } \\
\text { Rio Doce }\end{array}$ & $\begin{array}{l}\text { MOTTA, E. M. P. L. et al. CARACTERIZAÇÃO DEMOGRÁFICA E } \\
\text { SOCIOECONOMICA DA POPULAÇÃO ATINGIDA PELO ROMPIMENTO DA } \\
\text { BARRAGEM DO FUNDÃO. In: Encontro Nacional de Estudos Populacionais, 20., } \\
\text { 2016, Foz do Iguaçu. Anais... Foz do Iguaçu: ABEP, } 2016 .\end{array}$ & $\begin{array}{l}\text { CEDEPLAR- Centro } \\
\text { de Desenvolvimento } \\
\text { e Planejamento } \\
\text { Regional - } \\
\text { Universidade Federal } \\
\text { de Minas Gerais } \\
\end{array}$ \\
\hline $\begin{array}{l}\text { Toda a Bacia do } \\
\text { Rio Doce }\end{array}$ & $\begin{array}{l}\text { BARCELOS, E. et al. A caravana territorial da Bacia do Rio Doce: Mineração e } \\
\text { territorialidades em tensão. Terra Livre, [S.1.], v. 43, n. 2, p. 225-266, } 2016 .\end{array}$ & $\begin{array}{l}\text { Associação dos } \\
\text { Geógrafos Brasileiros }\end{array}$ \\
\hline $\begin{array}{l}\text { Toda a Bacia do } \\
\text { Rio Doce }\end{array}$ & $\begin{array}{l}\text { FELIPPE, M. F. et al. A tragédia do Rio Doce: a lama, o povo e a água. Belo } \\
\text { Horizonte, Juiz de Fora: [s.n.], 2016. } 27 \text { p. }\end{array}$ & $\begin{array}{l}\text { Universidade Federal } \\
\text { de Minas Gerais e } \\
\text { Universidade Federal } \\
\text { de Juiz de Fora }\end{array}$ \\
\hline $\begin{array}{l}\text { Toda a Bacia do } \\
\text { Rio Doce }\end{array}$ & $\begin{array}{l}\text { JOHAS, F. S. Análise do passivo socioeconômico do rompimento da barragem de } \\
\text { Fundão (Mariana MG) em novembro de } 2015 \text { na bacia do Rio Doce. } 2017.57 \text { f. } \\
\text { Monografia (Bacharel em Engenharia de Produção), Escola de Engenharia, } \\
\text { Universidade Federal Fluminense, Niterói, } 2017 .\end{array}$ & $\begin{array}{l}\text { Universidade Federal } \\
\text { Fluminense }\end{array}$ \\
\hline $\begin{array}{l}\text { Toda a Bacia do } \\
\text { Rio Doce }\end{array}$ & $\begin{array}{l}\text { AGÊNCIA NACIONAL DE ÁGUAS. Encarte Especial sobre a Bacia do Rio Doce: } \\
\text { Rompimento da Barragem em Mariana. Brasília, } 2016 .\end{array}$ & $\begin{array}{l}\text { Agência Nacional de } \\
\text { Águas }\end{array}$ \\
\hline $\begin{array}{l}\text { Toda a Bacia do } \\
\text { Rio Doce }\end{array}$ & $\begin{array}{l}\text { BARBOSA, F. A. R. ; et al. O desastre de Mariana e suas consequências sociais, } \\
\text { econômicas, políticas e ambientais: porque evoluir da abordagem de Gestão dos } \\
\text { recursos naturais para Governança dos recursos naturais? Arquivos do Museu de } \\
\text { História Natural e Jardim Botânico - UFMG, Belo Horizonte, v. 24, n. 1/2, p. 159- } \\
\text { 182, } 2015 \text {. }\end{array}$ & $\begin{array}{l}\text { Universidade Federal } \\
\text { de Minas Gerais }\end{array}$ \\
\hline $\begin{array}{l}\text { Toda a Bacia do } \\
\text { Rio Doce }\end{array}$ & $\begin{array}{l}\text { FELIPPE, M. F. et al. Acabou-se o que era Doce: notas geográficas sobre a construção } \\
\text { de um desastre ambiental. In: MILANEZ, B.; LOSEKANN, C. Desastre no Vale do } \\
\text { Rio Doce: Antecedentes, impactos e ações sobre a destruição. Rio de Janeiro: Folio } \\
\text { Digital, 2016. cap. 3, p. 125-162. }\end{array}$ & $\begin{array}{l}\text { TERRA/Universidade } \\
\text { Federal de Juiz de } \\
\text { Fora (Temáticas } \\
\text { Especiais } \\
\text { Relacionadas ao } \\
\text { Relevo e à Água) e } \\
\text { LESTE/Universidade } \\
\text { Federal de Minas } \\
\text { Gerais (Laboratório } \\
\text { de Estudos } \\
\text { Territoriais). Livro } \\
\text { UFES. }\end{array}$ \\
\hline $\begin{array}{l}\text { Toda a Bacia do } \\
\text { Rio Doce }\end{array}$ & $\begin{array}{l}\text { FAGUNDES, H. O. ; et al. Análise dos sedimentos em suspensão na Bacia } \\
\text { Hidrográfica do Rio Doce com imagens de satélite. In: Congresso Internacional de } \\
\text { Hidrossedimentologia, 2., 2017, Foz do Iguaçu. Anais... Foz do Iguaçu: ABRH, } 2017 .\end{array}$ & $\begin{array}{l}\text { Universidade Federal } \\
\text { do Rio Grande do Sul }\end{array}$ \\
\hline $\begin{array}{l}\text { Toda a Bacia do } \\
\text { Rio Doce }\end{array}$ & $\begin{array}{l}\text { LACERDA, R. C. A. O uso do PSA como instrumento econômico na recuperação } \\
\text { ambiental da bacia do Rio Doce. 2017. } 177 \text { f. Dissertação (Mestrado em Gestão } \\
\text { Econômica do Meio Ambiente) - Universidade de Brasília, Brasília, } 2017 .\end{array}$ & $\begin{array}{l}\text { Universidade de } \\
\text { Brasília }\end{array}$ \\
\hline $\begin{array}{l}\text { Toda a Bacia do } \\
\text { Rio Doce }\end{array}$ & $\begin{array}{l}\text { ZHOURI, A. et al. O desastre do Rio Doce: Entre as políticas de reparação e a gestão } \\
\text { das afetações. In: ZHOURI, A. (Org). Mineração, Violências e Resistências: Um } \\
\text { campo aberto à produção de conhecimentos no Brasil. Marabá (Pará): iGuana, } 2018 . \\
\text { cap. 1, p. 28-64. }\end{array}$ & $\begin{array}{l}\text { GESTA- } \\
\text { Universidade Federal } \\
\text { de Minas Gerais. } \\
\text { Livro Associação } \\
\text { Brasileira de } \\
\text { Antropolgia (ABA) }\end{array}$ \\
\hline $\begin{array}{l}\text { Toda a Bacia do } \\
\text { Rio Doce }\end{array}$ & $\begin{array}{l}\text { SOUSA, L. S. S. Caso Samarco- Análise dos Impactos Econômico-Financeiro Após } \\
\text { o Desastre. Monografia (Bacharel em Ciências Contábeis) Faculdade de } \\
\text { Administração, Ciências Contábeis e Economia, Universidade Federal de Goiás, } \\
\text { Goiânia, 2017. }\end{array}$ & $\begin{array}{l}\text { Universidade Federal } \\
\text { de Viçosa }\end{array}$ \\
\hline Toda a Bacia do & SAADI, A.; CAMPOS, J. C. F. Geomorfologia do caminho da lama: contexto e & Universidade Federal \\
\hline
\end{tabular}




\begin{tabular}{|c|c|c|}
\hline Rio Doce & $\begin{array}{l}\text { consequências da ruptura da Barragem do Fundão (novembro 2015-Mariana-MG). } \\
\text { Arquivos do Museu de História Natural e Jardim Botânico - UFMG, Belo } \\
\text { Horizonte, v. 24, n. 1/2, p. 63-103, } 2015 .\end{array}$ & de Minas Gerais \\
\hline $\begin{array}{l}\text { Toda a Bacia do } \\
\text { Rio Doce }\end{array}$ & $\begin{array}{l}\text { GONÇALVES, F. A. F.; BRANTES, H. A. Mapeamento Temático para Suporte à } \\
\text { Tomada de Decisão: Bacia do Rio Doce após Rompimento da Barragem de } \\
\text { Fundão. Trabalho de Conclusão de Curso (Graduação em Engenharia Ambiental) - } \\
\text { Universidade Federal do Rio de Janeiro. } 2016\end{array}$ & $\begin{array}{l}\text { Universidade Federal } \\
\text { do Rio de Janeiro }\end{array}$ \\
\hline $\begin{array}{l}\text { Toda a Bacia do } \\
\text { Rio Doce }\end{array}$ & $\begin{array}{l}\text { MINAS GERAIS. Secretaria de Estado de Desenvolvimento Regional, Política } \\
\text { Urbana e Gestão Metropolitana. Relatório: avaliação dos efeitos e desdobramentos do } \\
\text { rompimento da Barragem de Fundão em Mariana-MG. Belo Horizonte, } 2016 .\end{array}$ & $\begin{array}{l}\text { Secretaria de Estado } \\
\text { de Desenvolvimento } \\
\text { Regional, Política } \\
\text { Urbana e Gestão } \\
\text { Metropolitana - MG }\end{array}$ \\
\hline $\begin{array}{l}\text { Toda a Bacia do } \\
\text { Rio Doce }\end{array}$ & $\begin{array}{l}\text { SILVA, D. L.; FERREIRA, M. C.; SCOTTI, M. R. O maior desastre ambiental } \\
\text { brasileiro: de Mariana (MG) a Regência (ES). Arquivos do Museu de História } \\
\text { Natural e Jardim Botânico - UFMG, Belo Horizonte, v. 24, n. 1/2, p. 136-158, } 2015 .\end{array}$ & $\begin{array}{l}\text { Universidade Federal } \\
\text { de Minas Gerais }\end{array}$ \\
\hline $\begin{array}{l}\text { Toda a Bacia do } \\
\text { Rio Doce }\end{array}$ & $\begin{array}{l}\text { OMACHI, C. et al. Atlantic Forest loss caused by the world's largest tailing dam } \\
\text { collapse (Fundão Dam, Mariana, Brazil). Remote Sensing Applications, [S.1.], v. 12, } \\
\text { p. } 30-34,2018 \text {. }\end{array}$ & $\begin{array}{l}\text { Universidade Federal } \\
\text { do Rio de Janeiro, } \\
\text { Universidade de São } \\
\text { Paulo, INPE }\end{array}$ \\
\hline $\begin{array}{l}\text { Toda a Bacia do } \\
\text { Rio Doce }\end{array}$ & $\begin{array}{l}\text { VARGAS, I. B. ; et al. POTENCIAL MUTAGÊNICO E GENOTÓXICO DE } \\
\text { PEIXES EXPOSTOS AO SEDIMENTO DO RIO DOCE APÓS O } \\
\text { ROMPIMENTO DA BARRAGEM. In: XX Encontro Latino Americano de } \\
\text { Iniciação Científica, São José dos Campos. Educação e Ciência para cidadania global, } \\
2016 .\end{array}$ & $\begin{array}{l}\text { Universidade } \\
\text { Estadual do Norte } \\
\text { Fluminense Darcy } \\
\text { Ribeiro, Universidade } \\
\text { Federal do Espírtio } \\
\text { Santo, Instituto } \\
\text { Federal do Espírito } \\
\text { Santo. }\end{array}$ \\
\hline $\begin{array}{l}\text { Toda a Bacia do } \\
\text { Rio Doce }\end{array}$ & $\begin{array}{l}\text { DORNELAS, R. S. Diálogos de saberes em meio ao desastre: Reflexões e práticas a } \\
\text { partir do Organon - Núcleo de Estudo, Pesquisa e Extensão em Mobilizações Sociais. } \\
\text { In: LOSEKANN, C.; MAYORGA, C. (Org.). Desastre na Bacia do Rio Doce: } \\
\text { desafios para a universidade e para instituições estatais. Rio de Janeiro: Folio Digital } \\
\text { Letra e Imagem, 2018. cap. 2, p. 45-70. }\end{array}$ & $\begin{array}{l}\text { Organon - Núcleo de } \\
\text { Estudo, Pesquisa e } \\
\text { Extensão em } \\
\text { Mobilização Social, } \\
\text { da Universidade } \\
\text { Federal } \\
\text { do Espírito Santo } \\
\end{array}$ \\
\hline $\begin{array}{l}\text { Toda a Bacia do } \\
\text { Rio Doce }\end{array}$ & $\begin{array}{l}\text { SANTOS, J. A. D. ; et al. Primeiro levantamento de ictiofauna da bacia do rio } \\
\text { Doce após o rompimento da barragem de rejeito da Samarco, em Mariana-MG. } \\
\text { Universidade Federal de Viçosa. Viçosa. Abril } 2017 .\end{array}$ & $\begin{array}{l}\text { Universidade Federal } \\
\text { de Viçosa }\end{array}$ \\
\hline $\begin{array}{l}\text { Toda a Bacia do } \\
\text { Rio Doce }\end{array}$ & $\begin{array}{l}\text { COELHO, R. M. et al. Programa de qualidade de água e sedimento. Belo } \\
\text { Horizonte: RMPC \& Consultores Hídricos, } 201 \text { ? }\end{array}$ & RMPC Consultoria \\
\hline $\begin{array}{l}\text { Toda a Bacia do } \\
\text { Rio Doce }\end{array}$ & $\begin{array}{l}\text { LOPES, L. M. N. O rompimento da barragem de Mariana e seus impactos } \\
\text { socioambientais. Sinapse Múltipla, [S.1.], v. 5, p. 1-14, } 2016 .\end{array}$ & $\begin{array}{l}\text { Universidade Federal } \\
\text { Fluminense }\end{array}$ \\
\hline $\begin{array}{l}\text { Toda a Bacia do } \\
\text { Rio Doce }\end{array}$ & $\begin{array}{l}\text { MENEGHIN, G. de S.; SILVA, N. M. A atuação do Ministério Público para garantir a } \\
\text { participação dos atingidos no processos de reparação dos direitos violados pelo } \\
\text { rompimento da barragem de Fundão operada pela Samarco em Mariana. In: } \\
\text { MILANEZ, B.; LOSEKANN, C. Desastre na Bacia do Rio Doce: desafios para a } \\
\text { universidade e para as instituições estatais. Rio de Janeiro: Folio Digital, 2016. cap. 7, } \\
\text { p.171-204 }\end{array}$ & $\begin{array}{l}\text { Livro Universidade } \\
\text { Federal do Espírito } \\
\text { Santo }\end{array}$ \\
\hline $\begin{array}{l}\text { Toda a Bacia do } \\
\text { Rio Doce }\end{array}$ & $\begin{array}{l}\text { RODRIGUES, D. E et al. Algumas análises sobre os impactos à saúde do desastre em } \\
\text { Mariana (MG). In: MILANEZ, B.; LOSEKANN, C. Desastre no Vale do Rio Doce: } \\
\text { Antecedentes, impactos e ações sobre a destruição. Rio de Janeiro: Folio Digital, } \\
\text { 2016. cap. 4, p.163-197. }\end{array}$ & $\begin{array}{l}\text { Rede Nacional de } \\
\text { Médicas e Médicos } \\
\text { Populares. Livro } \\
\text { UFES }\end{array}$ \\
\hline $\begin{array}{l}\text { Toda a Bacia do } \\
\text { Rio Doce }\end{array}$ & $\begin{array}{l}\text { FREITAS, C. M.; SILVA, M. A.; MENEZES, F. C. O desastre na barragem de } \\
\text { mineração da Samarco: fratura exposta dos limites do Brasil na redução de risco de } \\
\text { desastres. Ciência e Cultura, São Paulo, v. 68, p. 25-30, } 2016 .\end{array}$ & Fiocruz \\
\hline $\begin{array}{l}\text { Toda a Bacia do } \\
\text { Rio Doce }\end{array}$ & $\begin{array}{l}\text { DINIZ, C. F. S. Determinação multielementar em amostras de água da bacia do } \\
\text { Rio Doce após o acidente da Barragem de Fundão. Dissertação (Mestrado em } \\
\text { Química - Química Analítica), Instituto de Ciências Exatas, Universidade Federal de } \\
\text { Minas Gerais, Belo Horizonte, } 2018 .\end{array}$ & $\begin{array}{l}\text { Universidade Federal } \\
\text { de Minas Gerais }\end{array}$ \\
\hline $\begin{array}{l}\text { Toda a Bacia do } \\
\text { Rio Doce }\end{array}$ & $\begin{array}{l}\text { DIAS, C. A. et al. Impactos do rompimento da barragem de Mariana na Qualidade da } \\
\text { água do rio Doce. Revista Espinhaço, [S.1.], v. 7, n. 1, p. 21-35, } 2018 .\end{array}$ & $\begin{array}{l}\text { Universidade Federal } \\
\text { dos Vales do } \\
\text { Jequitinhinha e } \\
\text { Mucuri }\end{array}$ \\
\hline $\begin{array}{l}\text { Toda a Bacia do } \\
\text { Rio Doce }\end{array}$ & $\begin{array}{l}\text { LACAZ, F. A. C.; PORTO, M. F. S.; PINHEIRO, T. M. M. Tragédias brasileiras } \\
\text { contemporâneas: o caso do rompimento da barragem de rejeitos de Fundão/Samarco. } \\
\text { Rev. bras. saúde ocup., São Paulo, v. 42, n. 9, } 2017 .\end{array}$ & $\begin{array}{l}\text { Universidade Federal } \\
\text { de São } \\
\text { Paulo, Universidade } \\
\text { Federal de Minas }\end{array}$ \\
\hline
\end{tabular}




\begin{tabular}{|l|l|l|} 
& & Gerais e Fiocruz \\
\hline Toda a Bacia do & CÉSAR, P. S. M.; CARNEIRO, R. O ROMPIMENTO DA BARRAGEM EM & Fundação João \\
Rio Doce & MARIANA PARA AS POPULAÇÕES HISTORICAMENTE VULNERÁVEIS. & Pinheiro \\
& $\begin{array}{l}\text { REVISTA LIVRE DE SUSTENTABILIDADE E EMPREENDEDORISMO, } \\
\text { [S.l.], v. 2, p. 223-240, 2017. }\end{array}$ & \\
\hline $\begin{array}{l}\text { Toda a Bacia do } \\
\text { Rio Doce }\end{array}$ & $\begin{array}{l}\text { LIMA, G. et al. Uso de mananciais subterrâneos e superficiais como alternativa para } \\
\text { abastecimento público ao longo do Rio Doce. In: Congresso Brasileiro de Águas } \\
\text { Subterrâneas, 20., 2018, Campinas. Anais... Campinas: ABAS, 2018. }\end{array}$ & Fund. Renova \\
\hline
\end{tabular}

